\title{
SKILlS' SUbSTITUTABILITY AND TECHNOLOGICAL PROGRESS: U.S. STATES 1950-1990
}

\author{
ANTONIO CICCONE \\ GIOVANNI PERI
}

\begin{abstract}
CESIFO WORKING PAPER No. 1024
CAtegory 5: Fiscal Policy, Macroeconomics and Growth

SEPTEMBER 2003
\end{abstract}

An electronic version of the paper may be downloaded

- from the SSRN website:

www.SSRN.com

- from the CESifo website: www.CESifo.de 


\title{
SKILLS' SUBSTITUTABILITY AND TECHNOLOGICAL PROGRESS: U.S. STATES 1950-1990
}

\begin{abstract}
In this article we estimate the long-run aggregate elasticity of substitution between skilled and unskilled workers. This is an important parameter as it allows us to compute the skill biased technological progress (SBTP) from the evolution of relative wages. However, it is hard to estimate because skill supply is endogenous. We tackle the task by using instruments proposed by the labor literature as sources of exogenous variation of schooling achievements across U.S. States. They are the state laws on Compulsory Schooling Attendance and on Child Labor. We then calculate SBTP and, using growth accounting, we calculate Hicks neutral technological progress (HNTP) for U.S. states in each decade between 1950 and 1990.

JEL Code: J3, O3, R1.

Keywords: elasticity of substitution, skill biased technology, skilled and unskilled workers, U.S. states.

Antonio Ciccone

Department of Economics and Business

$U P F$

Ramon Trias Fargas 25-27

08005 Barcelona

Spain

Antonio.Ciccone@Econ.Upf.es

Giovanni Peri

Department of Economics

University of California, Davis

One Shield Avenue

Davis CA 95616

U.S.A.

Giovanni.peri@ucdvas.edu
\end{abstract}

We thank Daron Acemoglu, Paul Beaudry, Douglas Gollin, Claudio Michelacci, Enrico Moretti and participants to the ESPE meetings in New York and SED meetings in Paris, for useful suggestions and comments. Daron Acemoglu and Joshua Angrist very kindly provided their data to us. Giovanni Peri thanks the Institute of Governmental Affairs for partially funding this project. 


\section{Introduction}

Estimating precisely the aggregate elasticity of substitution between skilled and unskilled workers is an extremely important task. Development and growth economists need the long run estimate of such elasticity to assess the effect of an increase in schooling on average income (see, for instance, Hendricks 2002). Labor economists need such elasticity to measure the impact of increasing supply of highly skilled workers on the average returns to education. Analysts of technological progress need such elasticity to identify the effect of skill-biased technological progress on relative wages (see, for instance, Autor and Katz 1999, Katz and Murphy 1992). The main contribution of this paper is to produce more accurate and methodologically improved estimates of the aggregate long run elasticity of substitution between low skilled and high skilled workers. We then use these estimates to identify skill biased technological growth and Hicks neutral technological growth for U.S. states in the period 1950-1990.

Estimating properly the substitutability between low skilled and high skilled workers is made particularly urgent by the fact that the assumptions often used to combine aggregate factors into an aggregate production function (Linear or Cobb-Douglas) do not seem to work well in this case. On the one hand low skilled and high skilled workers do not appear to be perfect substitutes (their relative wage changes when the relative supply changes) and their supplies cannot simply be "added". On the other hand they seem easier to substitute for each other than a Cobb-Douglas combination (elasticity of substitution equal to one) would imply. It is not surprising, therefore, that aggregate data on supply and compensation of workers at the sector and state-level have been used since the seventies to produce estimates of this elasticity. Bowles (1970), Dougherty (1972), Fallon and Layard (1975) and more recently Katz and Murphy (1992) have all addressed this issue. The formidable difficulty of this task, however, is easy to explain. To identify the aggregate longrun elasticity of substitution between high and low skills we should observe the response of relative compensation of high and low skills to a change in their relative supply as other factors are being kept constant. In econometric terms we need an exogenous random variation of the aggregate supply of skills. Researchers, however, have soon realized that two important factors tend to vary systematically with the relative supply of skills across countries and over time inducing spurious correlations: physical capital and technology. Skill-biased technological progress (as in Acemoglu 1998, Acemoglu and Zilibotti 2001) or skill-complementary machine investments (as in Fallon and Layard 1975 or Krusell et al. 2000) affect the return to skills and also induce higher supply of them, as people respond to increased returns by getting higher education. Consider, for instance, open 
economies such as the U.S. states: it is very likely that the differentials in returns to skills would induce migration of skilled workers to states that pay large skill premia. Alternatively, people living in states with highly paid skills may decide to remain in school longer and accumulate more skills increasing their supply. This would induce a positive (reverse) link between skill supply and return to skills and would bias (towards zero) the estimate of the elasticity of substitution between skills in a regression of relative wages on relative skills. The bottom line is that it is very hard to identify an exogenous random variation in the aggregate supply of skills.

Other authors have relied on microeconomic estimates of the elasticity of substitution (Johnson 1997), or on restrictions and structural specifications (Krusell et al 2000, Caselli and Coleman 2002a, 2002b) or on simple assumptions such as the constancy over time of skill-bias technological change (Katz and Murphy 1992). Our contribution is to tackle the endogeneity problem in the classic way, using instrumental variables estimation. Given the centrality of this parameter we devote two sections of the paper ( 4 and 5) to discuss the validity of the instruments and to convince the reader of the robustness of our estimates. The labor literature has suggested and used excellent instruments for the supply of skills which, where available, could be used at the aggregate level as well. Child labor laws and compulsory schooling laws had an important impact in affecting the level of schooling across U.S. states, especially during the forties and fifties. In particular, as they mandated a certain number of years of schooling, they affected significantly the high school graduation rates of several cohorts of people. Moreover as their adoption was mainly driven by "philanthropic" and "ideal" motivations among legislators these laws were quite exogenous to the process of technological change and capital accumulation. The laws were state-specific and changed over the years so that they provide the needed exogenous variation over-time and acrossstates affecting the relative supply of skills. Acemoglu and Angrist (2000) collected information on these laws and first used them as instruments for schooling at the individual level. They argue convincingly in their work that these laws affected the marginal decision of people to graduate from high school and they were not endogenously affected by returns to skills. Our identifying assumption is similar to theirs, except that we only need schooling laws to be independent of the bias of technological change, a condition weaker that the independence from returns to schooling assumed by Acemoglu and Angrist (2000). We use their data on these laws at the aggregate state level as instruments for the skill distribution of workers at the state level. While reasonably exogenous the child-labor and compulsory-schooling laws turn out to be rather weak instruments. This is not a surprise as the laws affect weakly the rate of graduation from high school and we use them to instrument the whole relative supply of skills. Aware of such weakness we check the robustness of our estimates using methods more robust to weak instrument bias than 2SLS, such as 
LIML and Fuller LIML. We also add to the set of instruments the share of children below fifteen years of age in the state. This variable is strongly correlated with the relative supply of skills as younger workers in the period 1950-1990 entered the labor market with higher education than older workers. Moreover such variable is still likely to be exogenous to the technological adoption process. Using this method we estimate the elasticity of substitution between skilled and unskilled workers to be around 1.55 , possibly as large as 1.96 . Such estimates are quite precise and they rely on instruments that seem more exogenous than any other variable available for cross-country studies. We show that they correct for a significant OLS bias towards zero. The obtained estimates are not far from the other existing estimates from micro literature or from aggregate estimation so that, while our points are important methodologically, they do not produce drastically different estimates and confirm confidence in the existing estimates.

Using the estimated elasticity of substitution we can then measure the skill biased technological progress (SBTP) and the Hicks neutral technological progress (HNTP) across US states for each decade between 1950 and 1990. In particular we present a model, similar to Katz and Murphy (1992), in which the elasticity of substitution between high and low skills is the pivotal parameter in order to obtain, using accounting techniques, estimates of HNTP and SBTP. These two components of technological progress have been mostly studied separately up to these days ${ }^{2}$. Growth economists (since the seminal work of Solow, 1957, 1958) have focused on HNTP in the form of "the Solow Residual" attributing to it at least half of the growth in productivity in the last several decades ${ }^{3}$ (see Jones 2002, Klenow and Rodriguez-Clare 1997 among others). Labor economists have focused on SBTP in the analysis of the increase in the "skill premium" among U.S. in the eighties and nineties (see Berman et al. 1994, Bound and Johsnon 1992, Katz and Murphy 1992, Murphy and Welsh 1992). A form of technological progress that enhances the productivity of skilled workers relative to the productivity of the unskilled ones could be an important component, while not the only one, to explain such phenomenon (see Card and DiNardo 2002 for an excellent discussion of the issue).

An interesting fact emerges from our joint estimates of these two types of technological progress across U.S. states. A strong and significant negative correlation between Hicks-Neutral and skill biased progress existed across states since the fifties and strengthened in the eighties. States with higher skill biased technological growth had lower Hicks neutral technological growth and such trade off became stronger and tighter during the eighties. This is consistent with the idea of a "technological frontier", namely a "menu" of technological development options among which

\footnotetext{
${ }^{2}$ Recently the work of Caselli and Coleman (2000a) has looked at these two components of technological progress together.

${ }^{3}$ The remaining growth in labor productivity was due to physical and human capital accumulation.
} 
the representative firm in each state could choose. Different choices across states would generate the combinations of SBTP and HNTP that we estimate.

The rest of the paper is organized as follows. Section 2 briefly reviews the related literature. Section 3 presents the empirical specification and derives the equations used to calculate SBTP and HNTP. Section 4 discusses the data and the instruments and section 5 presents and discusses the estimates of the elasticity of substitution between skills. Section 6 analyzes the estimated SBTP and HNTP and documents the trade-off between them on a technological frontier for U.S. states. Section 7 concludes the paper.

\section{Related Literature}

The analysis of the elasticity of substitution between skilled and unskilled workers has gone hand in hand with the analysis of skill-biased technological change. Already in the seventies Fallon and Layard (1975) were puzzled by the fact that the secular increase in the supply of skilled workers in the fifties and sixties did not decrease the skill premium measured by relative wages. They explored the possibility of a skill-biased form of progress working through capital-skill complementarities. Griliches (1969), Bowles (1970) and Dougherty (1972) proposed models with an aggregate production function and constant elasticity of substitution (CES) between workers with different skills, to analyze substitutability of skills and shifts in productivity of different factors.

During the nineties the phenomenon of increased wage dispersion (in particular of increased skill premium, measured as relative wage of college vs. high school graduates) revived the interest and the need for a good estimate of the aggregate substitutability of skills. An influential article by Katz and Murphy (1992) still provides a much quoted reference able to explain changes in skill premia in the seventies and eighties using demand and supply of skills and a constant skill biased technological change over time. Our work builds on a similar frame as Katz and Murphy (1992) but improves on the identification and estimation of the elasticity of substitution between skills, addressing explicitly the issue of long-run substitution and endogeneity of skills. We also show that the CES framework, with constant elasticity of substitution between skills and time-varying technological progress is a good representation of aggregate production for US states. Moreover our model, by nesting the Katz and Murphy (1992) frame into a growth-accounting analysis, allows to measure sequentially skill-biased and Hicks neutral technological progress and to analyze whether there is a systematic relation between the two. 
The increase in skill premium of the eighties was followed in the U.S. by a surge of productivity since 1995 and this attracted the interest of several growth and labor economists. The information and communication technology (ICT) revolution was regarded as the new general purpose technology, which could potentially be the source of the early skill-biased progress (eighties) and of the later productivity surge of the nineties (for instance Gordon 2000, Jorgenson and Stiroh 2000, Oliner and Sichel 2000). The literature on increasing skill premium and on the productivity surge became interactive and recently some papers have framed this issue into what used to be called "theory of appropriate technology" (Atkison and Stiglitz 1969). Basu and Weil (1998) and Caselli and Coleman (2002a) explicitly model the choice of a country which is adopting a technology out of a menu of available ones. They stress that this is possible if there is a "menu" or a "frontier" of possible technological choices, some more intensive in skill-biased growth, other in Hicks-neutral growth. Caselli and Coleman (2002a) estimate such frontier for a large set of countries. Similarly Acemoglu (1998) and Acemoglu and Zilibotti (2001) model the direction of technological change as depending on the relative supply of skills in trying to explain the behavior of skill premium in the seventies and eighties. The present paper explores, for the first time at the U.S. State-level (19501990), the empirical task of measuring SBTP and HNTP. We can calculate the trade off between these two forms of progress on the technological frontier, and we can track how this trade off changed over the decades 1950-1990.

\section{The Model}

\subsection{The Production Function}

A homogeneous, perfectly tradable good $Y_{c t}$ is produced in state $c$ at time $t$ according to the following production function:

$$
Y_{c t}=\Omega_{c t} K_{c t}^{\alpha_{c}}\left[L_{c t}^{\sigma}+\Lambda_{c t} H_{c t}^{\sigma}\right]^{1-\alpha_{c}}
$$

The function is a Cobb-Douglas combination of physical capital $K_{c t}$ and of a CES composite factor of unskilled labor $L_{c t}$ and skilled labor $H_{c t}$. We allow for different shares of income to physical capital across states $\left(\alpha_{c}\right)$ but we assume that they do not change over time. In Section 6 we show that this has, in fact, been the case for U.S. states supporting our choice of a Cobb-Douglas aggregation of labor and physical capital. The elasticity of substitution between skilled and unskilled workers $(1 / 1-\sigma)$, on the other hand, is assumed to be equal across states and over time for 
the whole period ${ }^{4}$. This specification is similar to the one used by Katz and Murphy (1992) or by Krusell et al (2000) without equipment capital ${ }^{5}$. The elasticity of substitution between capital and the composite labor factor is imposed to be equal to 1 . This assumption simplifies the treatment of our model as we plan to focus on skill-biased (rather than capital-biased) technological progress. Caselli and Coleman (2002b) show that for the aggregate United States similar results on the efficiency of skilled and unskilled factors are obtained with this specification or with a nested CES that allows complementarity between skilled workers and physical capital. The elasticity of substitution between $L_{c t}$ and $H_{c t}$ is $\frac{1}{1-\sigma}$ with $\sigma<1 . \Lambda_{c t}$ is the skilled-labor effectiveness, relative to unskilled labor. We call it skill biased technological level. Its rate of change over time $\ln \left(\Lambda_{c t}\right)-\ln \left(\Lambda_{c t-1}\right)$ captures the bias of technological progress towards skilled labor and we call it skilled biased technological progress (SBTP). $\Omega_{c t}$ is a measure of Hicks neutral productivity. Given our specification it is not possible to distinguish whether it captures capital or unskilled labor efficiency. We call it Hicks Neutral technological level. Its rate of change over time $\left[\ln \left(\Omega_{c t}\right)-\ln \left(\Omega_{c t-1}\right)\right]$ captures the Hicks-neutral technological progress (HNTP). The above functional form for the production function is particularly appropriate for our purposes. First of all it allows the analysis of substitutability between high and low skills which would have been impossible in a fully Cobb-Douglas specification. Second it maintains an easy structure in the substitution between physical capital and labor inputs as a whole and matches the fact that capital share in income has been rather stable over time for each U.S. state. Finally it allows the joint analysis of technological progress that has neutral effect on productivity, and of technological progress that increases relative productivity of highly skilled workers. These two types of progress, as discussed above, have been under the scrutiny of the growth, labor and productivity literature and mostly analyzed and debated in the last decade. While most of the analysis has been concentrated on analyzing them across countries or over time we believe that it is interesting to look at different U.S. states over time as this sample probably provides the cleanest example of different technological combinations out of a common menu of opportunities.

Our goal is to use the observed wages, and the observed quantities and prices of factors, particularly of skilled and unskilled workers, to estimate the unobservable Hicks-neutral technological level and the skill-biased technological level. To do this we first need to estimate the parameter $\sigma$. Our key empirical constructs are obtained by simply manipulating the equalities between marginal productivity and return of factors reported below:

\footnotetext{
${ }^{4}$ We also check in Section 5.2 the stability of this elasticity across decades.

${ }^{5}$ Several works in applied microeconomics also use this specification of production. See Card (2002) for an overview.
} 


$$
\begin{aligned}
& \frac{\partial Y_{c t}}{\partial K_{c t}}=\alpha_{c} \Omega_{c t}\left(\frac{K_{c t}}{N_{c t}}\right)^{\alpha_{c}-1}\left[l_{c t}^{\sigma}+\Lambda_{c t} h_{c t}^{\sigma}\right]^{1-\alpha_{c}}=\left(R_{t}\right) \\
& \frac{\partial Y_{c t}}{\partial L_{c t}}=\left(1-\alpha_{c}\right) \Omega_{c t} l_{c t}^{\sigma-1}\left(\frac{K_{c t}}{N_{c t}}\right)^{\alpha_{c}}\left[l_{c t}^{\sigma}+\Lambda_{c t} h_{c t}^{\sigma}\right]^{\frac{1-\alpha_{c}}{\sigma}-1}=w_{c t}^{L} \\
& \frac{\partial Y_{c t}}{\partial H_{c t}}=\left(1-\alpha_{c}\right) \Omega_{c t} h_{c t}^{\sigma-1}\left(\frac{K_{c t}}{N_{c t}}\right)^{\alpha_{c}}\left[l_{c t}^{\sigma}+\Lambda_{c t} h_{c t}^{\sigma}\right]^{\frac{1-\alpha_{c}}{\sigma}-1} \Lambda_{c t}=w_{c t}^{H}
\end{aligned}
$$

In conditions (2)-(4) we expressed the variables in "per worker" terms. $N_{c t}$ is the total number of workers in state $c$ period $t$, given by the sum of skilled $H_{c t}$ and unskilled $L_{c t} .\left(K_{c t} / N_{c t}\right)$ is physical capital per worker and $l_{c t}$ and $h_{c t}$ are, respectively, the share of unskilled workers $\left(L_{c t} / N_{c t}\right)$ and the share of skilled workers $\left(H_{c} / N_{c t}\right)$ in state $c$ at time $t$. Equation (2) states that marginal productivity of physical capital in each state at time $t$ is equal to the common real rental cost of capital $R_{t}$ at time $\mathrm{t}^{6}$. Equation (3) states that marginal productivity of unskilled workers is equal to their wage $w_{c t}^{L}$ while equation (4) does the same with marginal productivity of skilled workers and the wage they receive, $w^{H}{ }_{c t}$.

\subsection{Identifying the Skill Biased and the Hicks Neutral Technological Levels}

Taking the ratio of conditions (3) and (4) we can immediately solve for $\Lambda_{\mathrm{ct}}$, the skill biased technological level:

$$
\Lambda_{c t}=\left(\frac{w_{c t}^{H}}{w_{c t}^{L}}\right)\left(\frac{h_{c t}}{l_{c t}}\right)^{1-\sigma}
$$

Equation (5) shows that we can calculate the skill biased technological Level using the relative wages of skilled and unskilled workers and their shares in total employment as long as we know the elasticity of substitution $1 /(1-\sigma)$. We postpone the discussion of identification and estimation of $\sigma$ to the next section. Proceeding to the identification of the Hicks neutral technological level, we can derive the expression for $\left(K_{c} / N_{c t}\right)$ from equation (2) and substitute it (3)

\footnotetext{
${ }^{6}$ The real rental cost of capital is equal to the real interest rate plus the depreciation rate of capital: $R_{t}=\left(r_{t}+\delta\right)$.
} 
and (4). We combine expression (3) and (4) using the fact that average wage ( $w_{c t}$ ) for state $c$ at time $t$ can be expressed as the weighted average of the wage of skilled and unskilled workers: $w_{c t}=l_{c t} w_{c t}^{L}+h_{c t} w_{c t}^{H}$, and we obtain:

$$
w_{c t}=\alpha_{c}^{\frac{\alpha_{c}}{1-\alpha_{c}}}\left(1-\alpha_{c}\right)\left(R_{t}\right)^{-\frac{\alpha_{c}}{1-\alpha_{c}}}\left(\Omega_{c t}\right)^{\frac{1}{1-\alpha_{c}}}\left[l_{c t}^{\sigma}+\Lambda_{c t} h_{c t}^{\sigma}\right]^{\frac{1}{\sigma}}
$$

Finally solving $\Omega_{\mathrm{ct}}$ out of equation (6) we obtain the following expression for the Hicks neutral Technological Level:

$$
\Omega_{c t}=\left(\frac{R_{t}}{\alpha_{c}}\right)^{\alpha_{c}}\left(\frac{w_{c t}}{\frac{\left(l_{c t}^{\sigma}+\Lambda_{c t} h_{c t}^{\sigma}\right)^{\frac{1}{\sigma}}}{1-\alpha_{c}}}\right)^{1-\alpha_{c}}
$$

Expression (7) can be used to calculate the Hicks neutral technological level, once we have the (previously calculated) parameters $\Lambda_{\mathrm{ct}}, \sigma$, and given the data on average wages, on the real rental cost of capital, on the share of income going to capital and on the supply of skilled and unskilled labor. Also, expression (7) is simple and easy to interpret. Let us call $\tilde{w}_{c t}=\left[w_{c t} /\left(l_{c t}^{\sigma}+\Lambda_{c t} h_{c t}^{\sigma}\right)^{\frac{1}{\sigma}}\right]$ the "adjusted average wage". The "adjustment factor" in the denominator depends on the elasticity of substitution between skills and on their shares in total employment. In the case of perfect substitutability between skilled and unskilled workers $(\sigma=1$ and $\left.\Lambda_{\mathrm{ct}}=1\right)$ the adjustment factor is one and we are back in the standard Cobb-Douglas case. Using this definition, expression (7) is the usual relationship that defines Hicks neutral Technological Progress in the "dual" version ${ }^{7}$ of growth accounting. In particular, taking expression (7) in the "logdifference" form that is more commonly used, we have:

$$
\Delta \ln \Omega_{c t}=\alpha_{c} \Delta \ln R_{t}+\left(1-\alpha_{c}\right) \Delta \ln \left(\widetilde{w}_{c t}\right)
$$

\footnotetext{
${ }^{7}$ The "Dual" version of growth accounting uses shares and prices of factors (rather than quantities) to infer total factor productivity. See for instance Hsieh (2002).
} 
The HNTP on the left side (called Solow-residual in the standard Cobb-Douglas case) is equal to the growth rate of the rental rate of capital, $R_{t}$, times the share of capital $\alpha_{c}$ plus the growth rate of "adjusted average wage", $\tilde{w}_{c t}$, times the share of labor $\left(1-\alpha_{c}\right)$.

Our empirical procedure consists simply in implementing empirically the steps described here. Once we have a good estimate of $\sigma$ we use (5) to calculate $\Lambda_{\mathrm{ct}}$ for the 48 US continental states (excluding Alaska and Hawaii), considering the 10-year data between 1950 and 1990. The HBTP is given by the $\log$ changes of $\Lambda_{\mathrm{ct}}$. Finally, using $\sigma$ and $\Lambda_{\mathrm{ct}}$, we calculate the HNTP $\left(\Delta \ln \Omega_{c t}\right)$ using (8).

\subsection{Identifying the Elasticity of Substitution between Skilled and Unskilled}

The procedure that we described above has, at its very foundation, the use of a good measure of the parameter $\sigma$ that determines the elasticity of substitution between skilled and unskilled workers. We focus on estimating robustly and consistently such parameter for the long run. Taking logs and re-arranging equation (5) we obtain the following relation:

$$
\ln \left(\frac{w_{c t}^{H}}{w_{c t}^{L}}\right)=\ln \left(\Lambda_{c t}\right)+(1-\sigma) \ln \left(\frac{L_{c t}}{H_{c t}}\right)
$$

Equation (9) shows that, were other terms constant, in particular were $\Lambda_{c t}$ constant in each state and over time, the percentage difference in relative factor price associated to one percentage difference in relative factor supply, would provide a measure of the inverse of the direct elasticity of substitution between skilled and unskilled workers. Under these assumptions, performing an OLS regression of $\ln \left(w^{H}{ }_{c t} / w^{L}{ }_{c t}\right)$ on $\ln \left(L_{c t} H_{c t}\right)$ would consistently estimate the value of $(1-\sigma)$ as coefficient on the dependent variable. Alternatively, if $\Lambda_{c t}$ were to change in each state and over time, but such changes were not correlated with the change of relative factor supplies in the state, we could still estimate consistently $(1-\sigma)$. An OLS regression of the change in log of relative wages on the change in log of relative factor supplies, pooling states together, would deliver consistent estimates as coefficient of the dependent variable. Unluckily, neither of the above assumptions is plausible. Certainly $\Lambda_{c t}$ differ over time and across US states as they depend on their initial 
technology and on the structure of production of each state. Moreover, as skilled workers move across states, it is plausible to think that they respond to skill-biased technology so that the relative supply of factors in a state is correlated with its skill biased technological level. Our hope to estimate $(1-\sigma)$ consistently is to perform an IV estimation using instruments that are correlated with the change in relative supply of skills for each state but are orthogonal to the state-specific skilled biased technological change. We believe that the schooling and child-labor laws gathered by the Acemoglu and Angrist (2000) and discussed in detail later, serve this purpose and are, to this days, the best instrument available for individual and state schooling levels.

\section{The Data and the Instruments}

\subsection{Factor Supplies}

As our model adopts the simplifying assumption that only two skill levels exist and they exhibit imperfect substitutability with each other, we need to map several levels of schooling into these two groups. We use individual data from the U.S. Census Public Use Microdata Sample to construct skill's supply and wages. We consider only U.S. born white males aged 22-58. This is done in order to eliminate any problem of gender and ethnic composition. The data are described in detail in the Appendix A. The data identify the highest degree attended for each person in the sample and we report in Table 1 the average share of each schooling group in the total US working population per census year. The four schooling groups identified by the data (High School Dropouts, High School Graduates, College Dropouts and College graduates) are then mapped into two skill groups. A simple way of doing this, similarly to what Katz and Murphy (1992) and Johnson (1997) do, is to assume that workers can be grouped into two categories of skills. Those without a degree (i.e. high school dropouts) did not learn sophisticated skills and are therefore type L, they are pure "low skills equivalents". Those who graduated from high school acquired skills becoming type H. Continued education after High School allows workers to accumulate more skills so that they increase their supply of "high skills equivalents" within the category H. Skilled workers (with at least a high school degree) are all perfect substitutes: receiving higher education is equivalent to increasing one's quantity of skills. Skilled and unskilled workers, on the other hand, are different factors of production. Within the group of perfectly substitutable skilled workers $\mathrm{H}$ we choose one level of schooling as the base-group. As described below in greater detail, we try with two different base groups. The supply of other groups is converted into "base-group" equivalents using their relative wages that captures their relative content of skills, as within groups workers are perfectly substitutable. 
Table 1:

Evolution of Schooling in the U.S. Working Population

\begin{tabular}{|l|l|l|l|l|}
\hline Year: & $\begin{array}{l}\text { Share of HS- } \\
\text { Dropouts } \\
\text { (average US) }\end{array}$ & $\begin{array}{l}\text { Share of HS } \\
\text { Graduates } \\
\text { (average US) }\end{array}$ & $\begin{array}{l}\text { Share of College } \\
\text { Dropouts } \\
\text { (average US) }\end{array}$ & $\begin{array}{l}\text { Share of College } \\
\text { Graduates } \\
\text { (average US) }\end{array}$ \\
\hline 1950 & 0.60 & 0.22 & 0.10 & 0.08 \\
\hline 1960 & 0.50 & 0.28 & 0.11 & 0.11 \\
\hline 1970 & 0.35 & 0.35 & 0.15 & 0.15 \\
\hline 1980 & 0.22 & 0.37 & 0.20 & 0.21 \\
\hline 1990 & 0.12 & 0.33 & 0.30 & 0.25 \\
\hline
\end{tabular}

Source: Author's Calculations on U.S. Census Public Use Microdata Samples 1950,60,70,80,90.

Imposing the cut-off between skilled and unskilled at the high-school level (rather than higher) is a choice motivated by three reasons. First our instruments, the compulsory attendance and child labor laws, are mainly affecting the margin of high-school graduation and by choosing high school dropouts as unskilled and high school graduates (and more) as skilled we maximize the correlation of the instruments with the relative skill supply. Second this type of categorization is very much in line with what done in the cross-country literature. Graduation from secondary school is the measure of human capital in several cross-countries studies (see Mankiw Romer and Weil 1992 and Bils and Klenow 1998 among others) and when two skill groups are explicitly considered they are usually secondary school graduates versus workers without secondary education (as in Caselli and Coleman 2002a or Hendricks 2002). Third, graduation from high school is probably the most important "fact" concerning education attainments of the labor force during the 1950-1990 period. The recent literature on skill premium in the US has used High School Graduates versus College Graduates as reference groups. However this has been probably the consequence of focusing on the 80's as the relevant decade. Table 1 shows that considering the period 1950-1990 a most relevant cause of increase in skills supply among workers is the increase in the share of high school graduates. The table shows that the single most dramatic change across educational groups for the period 1950-1990 is certainly the dramatic decrease of workers without a high school degree. That group decreased from a majority of the workers $(60 \%)$ in 1950 to a small minority $(12 \%)$ in 1990. The increase of college graduates, while large, is by no means as remarkable: that group increased from $8 \%$ of the working population in 1950 to $25 \%$ in 1990 . Also considering High School Dropouts as unskilled and the rest of the groups as skilled workers we have a nice monotonic behavior over all decades of their supplies, with the first group decreasing its share in the labor force and the second increasing it. To the contrary, considering High School graduates and 
College graduates as the two groups we have that both groups increased their shares up to 1980 and then the first group began shrinking.

Table2:

The evolution of relative and average real wages in the US

\begin{tabular}{|l|l|l|l|}
\hline Year: & $\mathbf{W}_{\mathbf{c o}} / \mathbf{W}_{\mathbf{h s}}$ & $\mathbf{W}_{\mathbf{c o}} / \mathbf{W}_{\text {hsd }}$ & $\begin{array}{l}\text { Average } \mathbf{W} \\
(\mathbf{1 9 5 0}=\mathbf{1})\end{array}$ \\
\hline 1950 & 1.20 & 1.34 & 1.00 \\
\hline 1960 & 1.36 & 1.69 & 1.41 \\
\hline 1970 & 1.45 & 1.95 & 2.22 \\
\hline 1980 & 1.45 & 1.98 & 2.02 \\
\hline 1990 & 1.76 & 2.55 & 2.53 \\
\hline Tot change in \% & $+46 \%$ & $+90 \%$ & $+153 \%$ \\
\hline
\end{tabular}

Source: Author's Calculations on U.S. Census Public Use Microdata Samples

1950,60,70,80,90. We used real weekly wages (1990 constant U.S.\$) for white males 40-50

years of age.

Table 2 shows also that the increase in skill premium is a much more dramatic phenomenon over the 1950-1990 interval if we consider the "College-HS Dropouts" premium, rather then the "College-High School" premium. The second premium almost doubled over those forty years while the first increased by less than 50\%. Also, while the "College-High School" premium did not increase during the seventies (this is known in the literature), the "College-HS Dropouts" premium increased in each decade. The table also reports the behavior of the average real wage, relative to its 1950 level. Notice that while the period 1950-1970 combined large growth of the skill-premium and large growth of the average wage, the following period 1970-90 experienced growth in skill premium (especially the 80's) but was much smaller growth rates of real wages.

As mentioned above we choose two ways of constructing the two skill groups. The main difference between them is how we calculate the average wage of each group, while the relative supply is calculated in a similar fashion. On one hand, both methods use High School Dropouts and their average wage (for white, males, 40-50 years) to measure $\mathrm{L}$ and $w^{L}$. On the other hand the first method considers college graduates as the "base group" in the High skilled group, while the second method considers High School Graduates as "base group" among the high skills. The first (and preferred) method converts the supply of high school graduates and college dropouts in Collegeequivalents (using relative wages) and considers the average wage of college graduates as $w^{H}$. The second method, aimed at maximizing the comparability with Caselli and Coleman (2002a), considers high school graduates as the base group for the high skill group. This method converts the supply of college dropouts and college graduates into high school equivalents using relative wages 
and uses the average wage of all people with high school or more education to calculate $w^{H}$. The two methods are rather similar and yield similar results. $l_{c t}$ and $h_{c t}$, the relative supply of high and low skills, are calculated relative to the total labor force across states and census years.

\subsection{Description and Quality of the Instruments}

It is hard to find credible instruments for the supply of skills in a state. Acemoglu and Angrist (2000) used data on state and year specific legal restriction to the minimum years of schooling in order to instrument for individual schooling attainments. We aggregate these instruments for individuals by state of residence in order to obtain instruments for state level of skills. The maximum age for school enrollment, the minimum dropout age, the minimum schooling required and the minimum age for a working permit are combined to calculate the minimum number of years of schooling mandated by the law in each state and year (1914-1963). It is convenient to summarize these laws in two sets of variables, one capturing the effect of compulsory attendance (CA) laws and the other capturing the effect of child labor (CL) laws. It turns out that the child labor laws prescribed a minimum number of years of schooling between 6 and 9 across states and years, while the compulsory attendance laws imposed a minimum between 8 and 11 years. In order to summarize the effects of these laws we associate to each individual eight dummies, CL6-CL9 and CA8-CA11 that capture the minimum years of schooling prescribed by the laws in the state in which she was resident, at the time she was 14. For instance the dummy CL7 is equal to one if the state of residence of the person, at the time she was 14 , had child labor laws imposing a minimum of 7 years of schooling and it is 0 otherwise. Similarly the variable, say, CA9 is equal to 1 for a person whose state of residence when she was 14 had compulsory attendance laws imposing a minimum of 9 years of schooling and it is 0 otherwise. The dummy CL6 is one for 6 years or less of compulsory schooling and CL9 is one for 9 years or more of compulsory schooling prescribed by Child Labor Laws. Similarly CA8 is one for 8 year or less and CA11 is one for 11 years or more of schooling prescribed by compulsory attendance laws. In the individual PUMS sample each person has only one of the CL6-CL9 dummies being equal to one and similarly for the CA8-CA11 dummies, while all other are 0. Aggregating individuals by state of residence we calculate the share of workers for which each of the CL6-CL9 and CA8-CA11 dummies are equal to one and we use those eight averages by state and census year as instruments. We assume that the state of current residence is also the state where people were residing at 14 . This implies that the correlation of instruments and skill supply comes from the group of people who were affected by the laws and did not change state. Such choice minimizes the problem of endogeneity of 
the location decision. The identifying assumption needed in order to use these variables as instruments for the relative supply of skills across U.S. states is that the change in laws affected the change of skill supply in a state across years but they were not affected by the adopted technology in a state over those years. Given that the time for implementing compulsory attendance and child labor laws across states was dictated by cultural and ideological reasons more than by productivity considerations this seems plausible. Moreover Acemoglu and Angrist (2000) show that these laws affected significantly the graduation rate from high school but not the educational attainments after high school of people in those states. Therefore they do not seem associated to other changes in educational structure that changed (unobserved) quality of education.

These dummies (6 in total, excluding one per group) have some explanatory power on the supply of the skilled and unskilled. We report in Table 3 the first stage regressions and some indicators of the power of the instruments on the measures of the relative skill supply calculated in several different ways. The explanatory power of the instruments is expressed as the F-test of the exclusion of the instruments from the first stage regression. This statistic captures the joint significance of instruments at the first stage. We also report the partial $\mathrm{R}^{2}$ measuring the variance of the independent variable orthogonal to all other exogenous control explained by the instruments. The first stage regressions include state dummies and a time trend as exogenous variables so that the identifying variation is given by within state across years change in the instruments.

Across the columns of Table 3 we use different measures of $\mathrm{H}_{\mathrm{ct}}$ to construct $\ln \left(\mathrm{H}_{\mathrm{ct}} / \mathrm{L}_{\mathrm{ct}}\right)$. Column 1-2 (and 5-6) use HS Dropouts and College graduates as base-group for L and H. In specification 1 and 5 we simply use relative supply of these two groups, while in specification 2 and 6 we attribute all the workers with at least a high school degree to the group $\mathrm{H}$, using relative wages as weights. Specification 3-4 (and 7-8) consider HS Dropouts and HS graduates as base-groups for L and H. In Specification 3 (and 7) we simply consider the relative supply of HS graduates and HS dropouts, while in 4 (and 8) we attribute all the workers with more than HS degree to group H using relative wages. 
Table 3:

First Stage Regressions

\begin{tabular}{|c|c|c|c|c|c|c|c|c|}
\hline & \multicolumn{4}{|c|}{ CA and CL } & \multicolumn{4}{|c|}{ CA and CL plus Share under 15} \\
\hline Specification & 1 & 2 & 3 & 4 & 5 & 6 & 7 & 8 \\
\hline CL7 & $\begin{array}{l}0.08 \\
(0.09)\end{array}$ & $\begin{array}{l}0.06 \\
(0.08)\end{array}$ & $\begin{array}{l}0.17 \\
(0.09)\end{array}$ & \begin{tabular}{|l|}
0.06 \\
$(0.08)$
\end{tabular} & $\begin{array}{l}0.05 \\
(0.08)\end{array}$ & $\begin{array}{l}0.02 \\
(0.07)\end{array}$ & $\begin{array}{l}0.02 \\
(0.07)\end{array}$ & \begin{tabular}{|l|}
0.15 \\
$(0.06)$
\end{tabular} \\
\hline CL8 & $\begin{array}{l}0.06 \\
(0.12)\end{array}$ & $\begin{array}{l}0.12 \\
(0.11)\end{array}$ & $\begin{array}{l}0.21 \\
(0.09)\end{array}$ & \begin{tabular}{|l|}
0.11 \\
$(0.11)$
\end{tabular} & \begin{tabular}{|l|}
0.06 \\
$(0.09)$
\end{tabular} & $\begin{array}{l}0.09 \\
(0.09)\end{array}$ & $\begin{array}{l}0.09 \\
(0.09)\end{array}$ & \begin{tabular}{|l|}
0.18 \\
$(0.08)$
\end{tabular} \\
\hline CL9 & $\begin{array}{l}0.05 \\
(0.12)\end{array}$ & $\begin{array}{l}0.07 \\
(0.11)\end{array}$ & $\begin{array}{l}0.22 \\
(0.10)\end{array}$ & \begin{tabular}{|l|}
0.10 \\
$(0.11)$
\end{tabular} & \begin{tabular}{|l|}
0.07 \\
$(0.09)$
\end{tabular} & $\begin{array}{l}0.07 \\
(0.09)\end{array}$ & $\begin{array}{l}0.06 \\
(0.09)\end{array}$ & \begin{tabular}{|l|}
0.19 \\
$(0.08)$
\end{tabular} \\
\hline CA9 & $\begin{array}{l}0.10 \\
(0.12)\end{array}$ & $\begin{array}{l}0.06 \\
(0.08)\end{array}$ & $\begin{array}{l}0.01 \\
(0.08)\end{array}$ & \begin{tabular}{|l|}
0.06 \\
$(0.08)$ \\
\end{tabular} & \begin{tabular}{|l|}
0.16 \\
$(0.11)$ \\
\end{tabular} & $\begin{array}{l}0.13 \\
(0.09)\end{array}$ & $\begin{array}{l}0.13 \\
(0.09)\end{array}$ & \begin{tabular}{|l|}
0.05 \\
$(0.08)$ \\
\end{tabular} \\
\hline CA10 & $\begin{array}{l}0.16 \\
(0.12)\end{array}$ & $\begin{array}{l}0.19 \\
(0.11)\end{array}$ & $\begin{array}{l}0.07 \\
(0.09)\end{array}$ & \begin{tabular}{|l|}
0.19 \\
$(0.110$
\end{tabular} & \begin{tabular}{|l|}
0.10 \\
$(0.10)$
\end{tabular} & $\begin{array}{l}0.12 \\
(0.09)\end{array}$ & $\begin{array}{l}0.10 \\
(0.10)\end{array}$ & \begin{tabular}{|l|}
0.05 \\
$(0.08)$
\end{tabular} \\
\hline CA11 & $\begin{array}{l}0.12 \\
(0.13)\end{array}$ & $\begin{array}{l}0.10 \\
(0.12)\end{array}$ & $\begin{array}{l}0.06 \\
(0.10)\end{array}$ & \begin{tabular}{|l|}
0.11 \\
$(0.11)$
\end{tabular} & $\begin{array}{l}0.05 \\
(0.11)\end{array}$ & $\begin{array}{l}0.10 \\
(0.10)\end{array}$ & $\begin{array}{l}0.03 \\
(0.08)\end{array}$ & \begin{tabular}{|l|}
0.04 \\
$(0.09)$
\end{tabular} \\
\hline Under 15 & & & & & \begin{tabular}{|l|}
0.024 \\
$(0.004)$ \\
\end{tabular} & $\begin{array}{l}0.03 \\
(0.003) \\
\end{array}$ & $\begin{array}{l}0.02 \\
(0.003)\end{array}$ & \begin{tabular}{|l|}
0.016 \\
$(0.003)$ \\
\end{tabular} \\
\hline Partial $\mathrm{R}^{2}$ & 0.051 & 0.056 & 0.058 & 0.056 & 0.51 & 0.52 & 0.50 & 0.60 \\
\hline F-test & $1.80 *$ & $1.84 *$ & $2.56 * *$ & $1.84 *$ & $7.3 * * *$ & $13.4^{* * * *}$ & $7.1 * * *$ & $14.8 * * *$ \\
\hline $\begin{array}{l}\text { Test of Over- } \\
\text { identifying } \\
\text { Restrictions }^{\mathrm{a}}\end{array}$ & $\begin{array}{l}1.68 \\
(12.59)\end{array}$ & $\begin{array}{l}4.8 \\
(12.59)\end{array}$ & $\begin{array}{l}3.36 \\
(12.59)\end{array}$ & \begin{tabular}{|l|}
9.6 \\
$(12.59)$
\end{tabular} & \begin{tabular}{|l|}
2.88 \\
$(14.07)$
\end{tabular} & $\begin{array}{l}4.8 \\
(14.07)\end{array}$ & $\begin{array}{l}5.04 \\
(14.07)\end{array}$ & \begin{tabular}{|l|}
12.01 \\
$(14.07)$
\end{tabular} \\
\hline
\end{tabular}

Dependent Variable: $\ln \left(\mathrm{H}_{\mathrm{ct}} / \mathrm{L}_{\mathrm{ct}}\right)$. All first stage regressions include state fixed effects and Time trend. Standard errors in parenthesis.

Specification 1 and 5: $\ln \left(\mathrm{H}_{\mathrm{c}} / \mathrm{L}_{\mathrm{ct}}\right)$ calculated using $\mathrm{H}_{\mathrm{ct}}=$ number of college graduate only, $\mathrm{L}_{\mathrm{c}}=$ number of $\mathrm{HS}$ dropouts.

Specification 2 and 6: $\ln \left(\mathrm{H}_{\mathrm{ct}} / \mathrm{L}_{\mathrm{ct}}\right)$ calculated using $\mathrm{H}_{\mathrm{cl}}=$ number of college graduate plus college-equivalents of $\mathrm{HS}$ graduates and College dropouts, $\mathrm{L}_{\mathrm{ct}}=$ number of HS dropouts.

Specification 3 and 7: $\ln \left(\mathrm{H}_{\mathrm{ct}} / \mathrm{L}_{\mathrm{ct}}\right)$ calculated using $\mathrm{H}_{\mathrm{ct}}=$ number of High School Graduates only, $\mathrm{L}_{\mathrm{ct}}=$ number of HS dropouts.

Specification 4 and 8: $\ln \left(\mathrm{H}_{\mathrm{c} /} / \mathrm{L}_{\mathrm{ct}}\right)$ calculated using $\mathrm{H}_{\mathrm{ct}}=$ number of High School Graduates plus HS-equivalents of College dropouts and College Graduates, $\mathrm{L}_{\mathrm{ct}}=$ number of HS dropouts.

The test of over-identifying restrictions used is the version of the Hausman Test corrected for Heteroskedasticity as described in Woolridge (2001) pag 123.

$*=$ reject the exclusion restriction at $10 \%$

$* *=$ reject the exclusion restriction at $5 \%$

$* * *=$ reject the exclusion restriction at $1 \%$

${ }^{a}=$ the $95 \%$ critical value of the statistic is in parenthesis.

The significance of each of the CA and CL variables, singularly taken, is rarely high and, as expected, they always enter positively in explaining the relative supply of skills. The inclusion of $\mathrm{CA}$ and CL variables together, however, is never rejected at the $10 \%$ significance level. The variance of the dependent variable explained by the CA-CL instruments only is not too large (between 3 and 6\%) so our instruments are somewhat weak. To cope with this problem we take two steps. First, when using CA and CL only as instruments we adopt, besides 2SLS, other estimation procedures which have been proven to be more robust to weak instrument bias in small samples. The methods of estimations that we use are Limited Information Maximum Likelihood (LIML) 
recommended by Chao and Swanson (2002) in the case of many weak instruments and the Fullermodified LIML recommended by Stock, Wright and Yogo (2002) and by Hahn and Hausman (2002). Second, in order to increase the explanatory power of the instruments we introduce a variable that captures the demographic structure of the states and is probably important to determine the differential impact of state laws on skill supply. This variable is the share of population whose age is below 15 in each of census years. As schooling laws have produced progressively better educated younger generations, states with a larger fraction of young population at the beginning of each decade experienced larger increases in skill supply. While the variables based on CA-CL laws capture the presence of an institutional change in the state, the share of people below 15 captures the part of the population on which this change may have an important impact.

Column 5 to 8 of Table 3 shows that such instrument is highly correlated with the dependent variable and the F-test of exclusion is now consistently larger than 7 and, in the case of skill supply obtained using all education groups, the F-test of exclusion is above 13. Arguably the demographic variable is less exogenous than child labor laws as the fertility choices of people could depend endogenously on productivity or technological change ${ }^{8}$. However, trusting the exogeneity of child labor laws we perform a Hausman test on the over-identifying restrictions in the 2SLS specification (last column of the table) when we include all the CA-CL and the share of people below 15. The test does not reject the null hypothesis that none of the instruments (including the share of people below 15 in the state) enter the second stage equation. The restrictions are tested allowing for heteroskedasticity of the residuals. We use the version of the test in Woolridge (2001) page 123. The null hypothesis is never rejected at standard significance levels (5\%). All in all we believe that the CA-CL laws, complemented by the demographic variable, provide credible, exogenous and robust, instruments for the supply of skills. We use the whole set in estimating the elasticity of substitution between skilled and unskilled.

\section{Estimates}

\subsection{Elasticity of Substitution between Skills}

\footnotetext{
${ }^{8}$ This has been argued recently, for instance, by Doepke and Zilibotti (2003)
} 
Table 4

Estimates of (1- $\sigma)$ from equation (9)

\begin{tabular}{|c|c|c|c|c|}
\hline \multirow[b]{2}{*}{ Specification } & \multicolumn{2}{|c|}{$\begin{array}{l}\text { Base-Groups: HS Dropouts } \\
\text { and College Graduates }\end{array}$} & \multicolumn{2}{|c|}{$\begin{array}{l}\text { Base-Groups: HS Dropouts } \\
\text { and HS graduates }\end{array}$} \\
\hline & $\mathbf{I}$ & II & III & IV \\
\hline Description & $\begin{array}{l}\text { Supply: } \\
2 \text { groups only }\end{array}$ & $\begin{array}{l}\text { Supply: } \\
\text { All Groups }\end{array}$ & $\begin{array}{l}\text { Supply: } \\
2 \text { Groups only }\end{array}$ & $\begin{array}{l}\text { Supply: } \\
\text { All Groups }\end{array}$ \\
\hline OLS & $\begin{array}{l}-0.15^{* * * *} \\
(0.01)\end{array}$ & $\begin{array}{l}-0.16^{* * *} \\
(0.01)\end{array}$ & $\begin{array}{l}-0.18^{* * *} \\
(0.01)\end{array}$ & $\begin{array}{l}-0.15 * * * \\
(0.01)\end{array}$ \\
\hline $\begin{array}{l}\text { OLS with state dummies and } \\
\text { time trend }\end{array}$ & $\begin{array}{l}0.39 * * * \\
(0.08) \\
\end{array}$ & $\begin{array}{l}0.35 * * * \\
(0.07) \\
\end{array}$ & $\begin{array}{l}0.32 * * * \\
(0.09) \\
\end{array}$ & $\begin{array}{l}0.29 * * * \\
(0.06) \\
\end{array}$ \\
\hline $\begin{array}{l}\text { IV with state dummies and time } \\
\text { trend (using state of residence } \mathbf{C A} \\
\text { and } \mathbf{C L} \text { ) }\end{array}$ & $\begin{array}{l}0.74 * * \\
(0.32)\end{array}$ & $\begin{array}{l}0.72 * * \\
(0.33)\end{array}$ & $\begin{array}{l}0.64^{*} \\
(0.35)\end{array}$ & $\begin{array}{l}0.57^{*} \\
(0.30)\end{array}$ \\
\hline $\begin{array}{l}\text { LIML with state dummies and } \\
\text { time trend (using state of residence } \\
\text { CA and CL) }\end{array}$ & $\begin{array}{l}0.79 * * \\
(0.28)\end{array}$ & $\begin{array}{l}0.83 * * \\
(0.33)\end{array}$ & $\begin{array}{l}0.58 * * \\
(0.23)\end{array}$ & $\begin{array}{l}0.61^{*} \\
(0.27)\end{array}$ \\
\hline $\begin{array}{l}\text { Fuller-modified LIML, } \alpha=\mathbf{1}, \\
\text { with state dummies and time trend } \\
\text { (using state of residence CA and } \\
\text { CL) }\end{array}$ & $\begin{array}{l}0.75 * * \\
(0.29)\end{array}$ & $\begin{array}{l}0.77 * * \\
(0.35)\end{array}$ & $\begin{array}{l}0.56 * * \\
(0.24)\end{array}$ & $\begin{array}{l}0.58^{* * *} \\
(0.28)\end{array}$ \\
\hline $\begin{array}{l}\text { Fuller-modified LIML, } \alpha=\mathbf{4} \text {, } \\
\text { with state dummies and time trend } \\
\text { (using state of residence CA and } \\
\text { CL) }\end{array}$ & $\begin{array}{l}0.67 * * \\
(0.25)\end{array}$ & $\begin{array}{l}0.67 * * \\
(0.29)\end{array}$ & $\begin{array}{l}0.50^{* *} \\
(0.21)\end{array}$ & $\begin{array}{l}0.51 * * \\
(0.24)\end{array}$ \\
\hline $\begin{array}{l}\text { IV with state dummies and time } \\
\text { trend (using CA-CL and share } \\
\text { under } 15 \text { as IV) }\end{array}$ & $\begin{array}{l}0.57 * * \\
(0.11)\end{array}$ & $\begin{array}{l}0.64 * * \\
(0.12)\end{array}$ & $\begin{array}{l}0.55^{* *} \\
(0.11)\end{array}$ & $\begin{array}{l}0.48^{* *} \\
(0.10)\end{array}$ \\
\hline $\begin{array}{l}\text { LIML with state dummies and time } \\
\text { trend (using state of residence CA } \\
\text { and CL and share under } \mathbf{1 5} \text { as IV) }\end{array}$ & $\begin{array}{l}0.54 * * \\
(0.13)\end{array}$ & $\begin{array}{l}0.55^{*} \\
(0.14)\end{array}$ & $\begin{array}{l}0.46 * * \\
(0.12)\end{array}$ & $\begin{array}{l}0.42 * * \\
(0.11)\end{array}$ \\
\hline $\begin{array}{l}\text { Fuller-modified LIML, } \alpha=1 \text {, with } \\
\text { state dummies and time trend (using } \\
\text { state of residence CA and CL and } \\
\text { share under } \mathbf{1 5} \text { as IV) }\end{array}$ & $\begin{array}{l}0.55 * * \\
(0.13)\end{array}$ & $\begin{array}{l}0.46^{* *} \\
(0.12)\end{array}$ & $\begin{array}{l}0.45^{* *} \\
(0.11)\end{array}$ & $\begin{array}{l}0.41 * * \\
(0.10)\end{array}$ \\
\hline $\begin{array}{l}\text { Fuller-modified LIML, } \alpha=\mathbf{4} \text {, with } \\
\text { state dummies and time trend (using } \\
\text { state of residence CA and CL and } \\
\text { share under } 15 \text { as IV) }\end{array}$ & $\begin{array}{l}0.54 * * \\
(0.13)\end{array}$ & $\begin{array}{l}0.45^{* *} \\
(0.12)\end{array}$ & $\begin{array}{l}0.45^{* *} \\
(0.11)\end{array}$ & $\begin{array}{l}0.42 * * \\
(0.10)\end{array}$ \\
\hline
\end{tabular}

Years: 1950-1990, 48 U.S. continental states, Tot. Observations 240

Heteroskedasticity Robust Standard Errors in Parenthesis

$*=$ significant at $10 \%$

$* *=$ significant at $5 \%$

$* * *=$ significant at $1 \%$

${ }^{a} \mathrm{~L}_{\mathrm{c}}=\mathrm{HS}$ Dropouts, $\mathrm{H}_{\mathrm{c}}=\mathrm{Co}+0.28 * \mathrm{HS}+0.50 * \mathrm{Co} \_$dropouts (weights from relative wages)

${ }^{\mathrm{b}} \mathrm{L}_{\mathrm{c}}=\mathrm{HS}$. Dropouts, $\mathrm{Hc}=\mathrm{HS}+1.78 \mathrm{CO}$ Dropouts $+3.57 \mathrm{CO}$ (weight from relative wages) 
Our key estimation results are shown in Table 4. We report the estimates of the parameter $(1-\sigma)$ from a regression like (9) in which we include state fixed effects, to account for different initial levels of the skill-biased technology across states and a common time trend that captures the average national skill biased progress. We adopt several estimation techniques using CA8-CA10 (referred to simply as CA) and CL7-CL9 (referred to simply as CL) as instruments for the variable $\ln \left(L_{c t} / H_{c t}\right)$ in rows 3-6 of Table 4. In some specifications (rows 7 to 10) we also include the share of population under 15 as instrument. In order to see the effect of the instrumental variable estimation on the coefficient estimates we first present (first row) the estimates of regression (9) using OLS, without any control and then (second row) with state and time dummies as controls. Our preferred specification, throughout the table, is the one in Column II in which we use HS Dropouts and College Graduates as base groups for the low-skills (L) and high skills (H) respectively in calculating $\ln \left(L_{c t} / H_{c t}\right)$. The relative wages used to compute $\ln \left(w_{c t}^{H} / w_{c t}^{L}\right)$ are those of white males 40 to 50 years old, with no degree $\left(\mathrm{w}^{\mathrm{L}}{ }_{c t}\right)$ or with a college degree $\left(\mathrm{w}^{\mathrm{H}}{ }_{\mathrm{ct}}\right)$. Column I, only differs because we use the HS Dropouts and College Graduate groups to construct the relative supply of skills without accounting for the rest of the workers. Column III and IV are the same as I and II but HS graduates (rather than College Graduates) and their wages are chosen as "base group" for high skilled. Low skilled workers are still represented by HS Dropouts.

Considering the OLS estimates without controls (first row) we find a positive (!) correlation between relative skill supply and relative returns of skills (i.e. the negative sign on the $1-\sigma$ coefficient). Such positive correlation was noted before in the literature that considered the behavior of the aggregate U.S. economy over time (Katz and Murphy 1992). This means that the endogeneity of skill supply and/or the skill-driven technological progress generates a strong positive correlation between $\Lambda_{\mathrm{ct}}$ and the supply of high-skilled workers across states: a higher share of highly skilled workers is associated with and higher skill-premium (rather than a lower) for the workers in that state. However, allowing for different initial technologies across states (state-effects) and for a common time trend in the skill-biased progress we obtain in the second row a negative correlation between skill supply and their returns. If the state-specific changes of skills were exogenous this row would provide a correct estimate of the elasticity of substitutions between skills. The value of such elasticity would be between 2.5 and 3.4 with a preferred estimate of 2.8. Such value for the elasticity is quite large and it certainly suffers from the possible bias due to endogeneity of skill supply across states.

In rows 3 through 6 we consider the $\mathrm{CL}$ and $\mathrm{CA}$ laws as instruments and we use several different estimation techniques. The third row shows the results from a 2 SLS estimation with robust standard errors, the fourth row shows the results from a LIML estimation and row five and six show 
estimates from the Fuller-modified LIML estimation, that corrects for the small sample bias of the LIML estimator . The parameter $\alpha$, is a positive number to be inputed in the calculation of the Fuller (1977)- modified LIML. A value of $\alpha=1$ as in row five delivers a "nearly unbiased" estimator, while a value of $\alpha=4$ as in row six produces the estimator with the lowest mean square error. The estimates for $(1-\sigma)$ in all specifications using CA and CL as instruments are significantly larger than in the case of OLS estimates. This confirms the presence of a downward OLS bias due to endogeneity of technological progress. The estimates of $(1-\sigma)$ vary between 0.51 and 0.83 with a mean and median estimate around 0.65. The standard errors of the estimates are not small. They range from 0.21 to 0.35 and this is clearly the result of the weakness of the instruments. Specifications in rows 7-10 include also the share of people below 15 as instrument, in order to increase the precision of the estimates. Again we use the four different methods (2SLS, LIML, Fuller LIML with $\alpha=1$ or 4$)$ and the four different specifications. Now the estimates of $(1-\sigma)$ are somewhat lower ranging between 0.42 and 0.64 (the average is around 0.5) and their standard errors are reduced to close to 0.10 . Balancing between the higher precision of the second set of estimates and the higher reliability of the instruments of the first set we consider the range 0.51-0.64 as the most appropriate. In this range the two sets of estimates overlap and also the preferred specification of Column II has average estimate around 0.65. Considering the preferred range of our estimates the elasticity of substitution between skills is within the interval [1.55 (=1/0.64), $1.97(=1 / 0.51)]$. Considering the whole range of estimates and their standard errors, however, the elasticity of substitution could be as large as 2.2 and as small as 1.25 . We discuss these estimates in the next section. However, we perform the analysis of skill biased and Hicks neutral technological level using $(1-\sigma)=0.64$ and $(1-\sigma)=0.51$ as our focal estimates. As the first value $(1-\sigma)=0.64$ is actually equal to the estimate in row 7 Column II we will refer sometimes to this one as "our preferred estimate".

\subsection{Stability of the elasticity over time}

Equation (9) and the subsequent empirical procedure assume that the parameter $\sigma$ is constant over time, while skill-biased technological level changes. While this is an assumption shared by large part of this literature we verify here that it is not contradicted by the data. Our model is meaningful only if we can explain relative change in wages as effect of changing skill-biased technological progress for given elasticity of substitution between skills. If also the elasticity parameter changed significantly over decades then identification become more dubious. An easy 
way to check this assumption is to test that the data do not reject constant elasticity over time. We do this by estimating (9) while allowing for different elasticity in the early period (1950-70) and in the more recent one (1970-90). We cannot estimate different elasticity each single decade as we want to control for state fixed effects. We perform such estimation on the preferred specification (Column II of Table 4) using 2SLS with CA-CL and the 2SLS with CA-CL and share under 15 (i.e. specification in row 3 and 7) allowing the elasticity to be different in the two periods. We obtain that estimates of $(1-\sigma)$ are equal to 0.63 (s.e. 0.12) before 1970 and 0.66 (s.e 0.16) post 1970 using CA-CL as IV, and they are 0.56 (s.e. 0.11 ) pre-1970 and 0.46 (s.e. 0.11) post 1970. A formal test of equality between the two coefficients does not reject the null of equal values in either case at the $10 \%$ confidence level. Similar results are obtained with other specifications, so that we are reassured that the estimated elasticity is not only appropriate for the recent decades but the data do not reject the hypothesis that it was constant over the whole period.

Table 5

Estimates of $\sigma$ in our work and in the literature

\begin{tabular}{|l|l|l|}
\hline Authors, Method and Sample & $\begin{array}{l}\text { Preferred } \\
\text { estimate of (1- } \boldsymbol{\sigma})\end{array}$ & Std Error \\
\hline $\begin{array}{l}\text { Ciccone and Peri } \\
\text { IV on panel of U.S. States }\end{array}$ & 0.64 & 0.12 \\
\hline $\begin{array}{l}\text { Fallon and Layard (1975) } \\
\text { Cross-country }\end{array}$ & 0.67 & 0.07 \\
\hline $\begin{array}{l}\text { Katz and Murphy (1992) } \\
\text { OLS on U.S. time series }\end{array}$ & 0.71 & 0.15 \\
\hline $\begin{array}{l}\text { Murphy et al. (1998) } \\
\text { OLS on Canada time-Series }\end{array}$ & 0.73 & 0.13 \\
\hline $\begin{array}{l}\text { Johnson (1997) } \\
\text { From micro-estimates }\end{array}$ & 0.66 & n.a. \\
\hline $\begin{array}{l}\text { Krusell et al. (2000) } \\
\text { U.S. time series }\end{array}$ & 0.60 & 0.23 \\
\hline $\begin{array}{l}\text { Caselli and Coleman (2000) } \\
\text { Cross-Country }\end{array}$ & 0.76 & 0.07 \\
\hline
\end{tabular}

\subsection{Comparison with Previous Estimates}

There are several estimates of the aggregate elasticity of substitution between more skilled and less skilled workers. Some times these estimates are framed in a nested CES production function in which capital is allowed to be a closer complement of skilled than unskilled labor, other 
times, as in our case, capital is assumed to be combined with skilled and unskilled labor in a "CobbDouglas" composite or it is ignored altogether. We review some of those estimates here. We will conclude that neither the above-mentioned differences in specification nor our methodological issues generate big differences in the estimates of elasticity of substitution. We consider only few other influential studies that provide a benchmark. Table 5 summarizes some of the existing estimates of the parameter $(1-\sigma)$ derived from aggregate production functions. Fallon and Layard (1975) analyzed skill and capital complementarity. They estimated (1- $\sigma)$ at 0.67 using 22 countries and a nested CES including capital as complement to high skills. They used a simultaneous equation approach, recognizing the problem of skill endogeneity across countries, but they used a rather poor instrument for the supply of skills, namely a measure of income per capita which is clearly correlated with technological level. More recently Katz and Murphy (1992) estimated an equation identical to (6) using the U.S. aggregate yearly time series. They used 25 observations (1963-1987) and assumed a constant and positive skill-biased technological growth during each year. They obtained a short-run estimate of $(1-\sigma)$ based on yearly variation equal to 0.71 . As mentioned, however, they did not address the issue of endogenous skill supply. Murphy et al (1998) applied the same method and procedure to data from Canada 1981-1995 and obtained an estimate of (1- $\sigma$ ) equal to 0.73 with a standard error of 0.13. Johnson (1997) followed the same approach as Katz and Murphy and adopted an estimate of (1- $\sigma)$ for his simulations equal to 0.66 . Finally two recent works that adopted the nested CES approach, estimated 1- $\sigma$ to be equal to 0.60 (Krusell et al 2000) and to 0.76 (Caselli and Coleman 2002a) using U.S. time series data and international cross sectional data respectively.

Our preferred estimate of the inverse of the elasticity of substitution between high and low skills, $(1-\sigma)=0.64$ is, therefore, in the same ballpark as the existing estimates. It is on the low part of the range (only one estimate is smaller) and about as precise as any other (only two have smaller standard errors). Compared to two existing estimates that use time-series data for the aggregate US (Katz and Murphy 1992 and Krusell at al. 2000) our estimate is right in between. We could argue that our elasticity estimate (1.55) is larger than Katz and Murphy (1992) because we use a longer interval of time (ten years) allowing better substitutability between the two factors. On the other hand our elasticity estimate is somewhat smaller than Krusell et al. (2000) but considering our preferred range for $(1-\sigma)$ that is $(0.51-0.64)$, their estimate is contain within it.

Our approach uses a different method, credible IV and high quality data and we regard it as an improvement on the methods used so far. The precision of the estimates, the exogeneity of the instruments, the ability to control for state and time effects, the homogeneity of data sources and of 
institutional and legal arrangements across states make us confident that we have a good point estimate of the elasticity of substitution between high and low skilled workers. The reassuring fact, in terms of the practice commonly adopted by the aggregate literature, is that the prevalent estimate of 1.5 as elasticity of substitution between skilled and unskilled, is also very close to what we find.

\section{Technological Progress}

\subsection{Skill-Biased Technological Progress}

Using our estimates of the parameter $\sigma$, namely 0.36 and 0.49 (the extremes of the preferred range), we calculate and describe in this section the general features of skill-biased technology and its growth across U.S. states. The average SBTP across states in each decade and the average SBTP for each state (1950-90) are reported in Tables A1, A2 and A3 of the appendix. In the appendix we report the values obtained using each of the two estimates of $\sigma$, however given that in most cases the qualitative results are rather similar we analyze and comment in this section prevalently the results from $\sigma=0.36$. First of all, SBTP is not a phenomenon that begins in the eighties. The whole period 1950-1990 experienced a continuous and stunning growth of skill biased technological level. Our estimates imply an average yearly SBTP of $4.8 \%$ during the 50's, 5.8\% during the sixties, 5.1\% during the seventies and $7.0 \%$ during the eighties. Certainly, during the eighties the phenomenon had a significant acceleration but this component of technological level has been growing dramatically since the 50's. While these numbers may seem very large the reader should keep in mind that such enormous SBTP is needed to ensure a doubling of the skill-unskilled premium during the 1950-1990 (See Table 2) vis-à-vis an eleven-fold increase in the relative supply of skilled (High School graduates and higher degrees) versus unskilled (High School Dropouts). Over the whole period SBTP was about 5.7\% per year with some differences across decades. This estimate is quite larger than what assumed in Katz and Murphy (1992) in which a constant trend growth for SBTP is used in equation (10) with a value of 3.3\% per year. Our definition of skills, though, differs from theirs as we use High School dropouts as low skills rather than High School Graduates.

Considering relative skill biased Technological levels across states one fact is worth noticing. Figure 1 and 2 show the distribution (re-centered in 0) of relative Skill-biased technological levels (i.e. $\ln \left(\Lambda_{\mathrm{ct}}\right)$ ) in 1950 and 1990. Figure 1 shows SBTL obtained when $\sigma=0.36$

while Figure 2 assumes $\sigma=0.49$. What is clear is that overall there has been an increase in the dispersion of skill-biased technological levels across states. States with higher initial skill biased technology had an overall tendency (in the 1950-90) to increase their advantage even further. Looking at Table A2 (or A3) to identify some of the fast- SBTP states we notice that several 
western states are in the top positions. Arizona and New Mexico, for instance, experienced average SBTP of 7-8\% for the whole period 1950-90. To the other end of the range more "rural states" such as the Dakotas and Rhode Island had SBTP below $4.5 \%$ per year.

Figure 1

Relative levels of Skill Biased Technology in U.S. states 1950 and $1990(\sigma=0.36)$

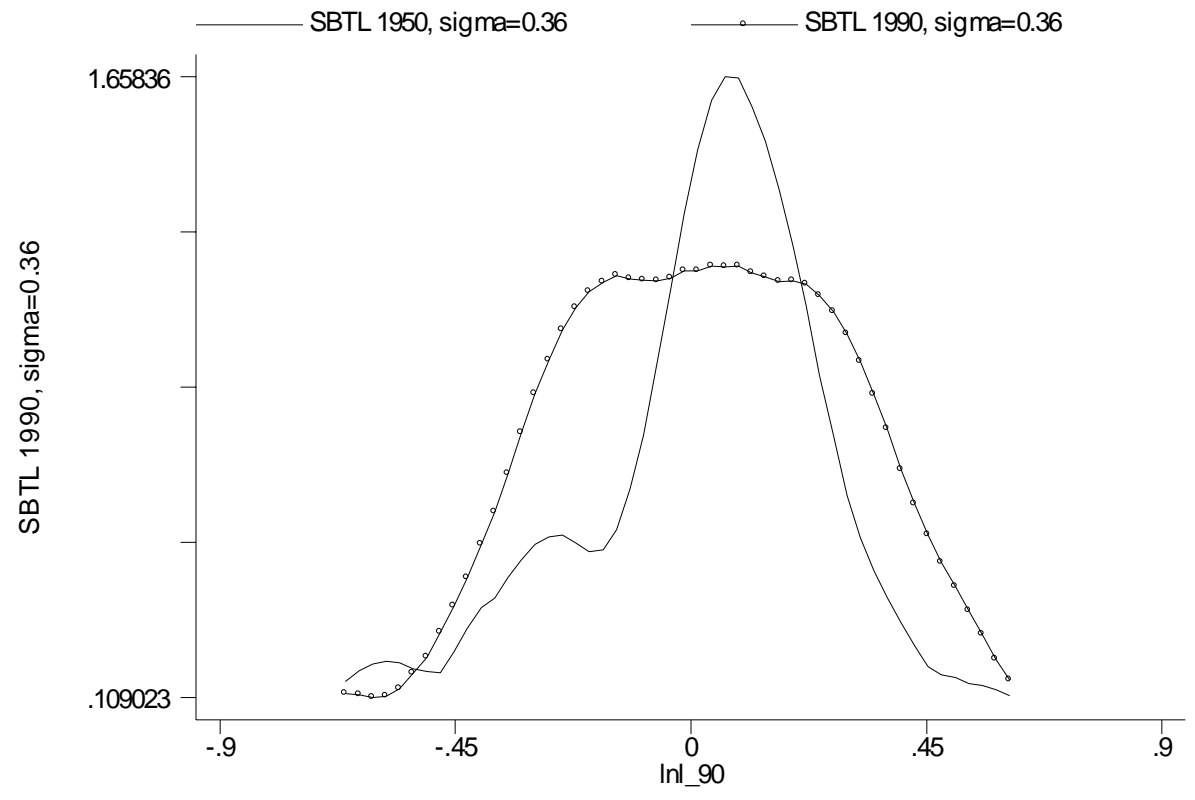

Figure 2

Relative levels of Skill Biased Technology in U.S. states 1950 and $1990(\sigma=0.49)$

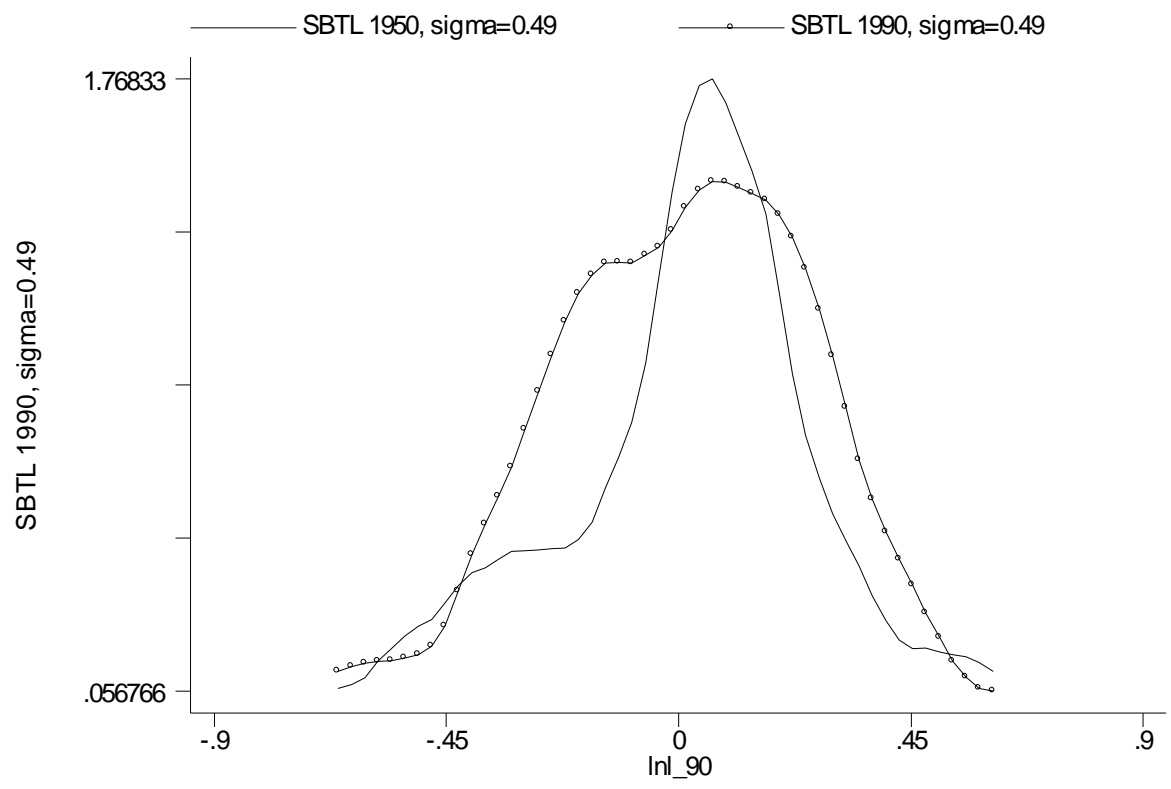




\subsection{Hicks Neutral Technological Progress}

With the estimates of $\sigma$ and $\Lambda_{\mathrm{ct}}$ at hands, we can use equation (8) to derive HNTP. Besides $\Lambda_{\mathrm{ct}}, \mathrm{h}_{\mathrm{ct}}, 1_{\mathrm{ct}}$, and $\sigma$, we also need measures of the real wage, of the real interest rate $\mathrm{r}_{\mathrm{t}}$ and of depreciation rate $\delta$ and, most importantly, of the share of capital in total production, $\alpha_{c}$. Real wage $w_{c t}$ is measured as average real weekly wage of male white workers between 22 and 59 years of age. This procedure minimizes any impact from racial and gender composition effect and corrects for differences in weeks worked. As measure of real interest rate $r_{t}$ in each census year we use the average real rate relative to the five previous years (e.g. 45-50 for 1950, 55-60 for 1960 and so on). The real interest rate is calculated as the annual rate on the three months T-bill net of "ex-post" inflation. As depreciation rate we use the most commonly used $\delta=10 \%$. Using this procedure we obtain the following values for $\mathrm{R}_{\mathrm{t}}=\left(r_{t}+\delta\right): 7 \%$ in $1950,11 \%$ in $1960,11 \%$ in $1970,8.1 \%$ in 1980 and $12.5 \%$ in 1990 . In order to calculate the share of capital for each state, $\alpha_{c}$ we use the state income accounts. We take the total gross state product net of indirect taxes as measure of total income. As measure of share of income to the labor factor we adopt the accurate procedure proposed by Gollin (2002). First we impute as labor income all the wage and salary income of employees. Then we calculate the average labor income of employees and we impute to selfemployed the same average labor income. The sum of measured labor income of employees and imputed labor income of self-employed is used as measure of total labor income. Dividing this by total income gives us an estimate of $\left(1-\alpha_{c}\right)$. The data for these variables are available from the Bureau of Economic Analysis, National Income and Production Accounts (http://www.bea.gov/bea/regional/spi/). At the state level they can be found for the period 19752000. We calculate $\alpha_{c t}$ for each state over this period. We checked that there is no relevant time variation of such share in each state over the period, by testing that no state has any significantly positive or negative time trend in their labor share. This is true for 45 out of 48 states. We use the average share 1975-2000 for each state as measure of its $\left(1-\alpha_{c}\right)$. While there are few outliers probably due to the composition of their productive sectors (Alaska and Wyoming with low labor shares and D.C. with high labor share) forty states have labor shares between 0.67 and 0.72 . Using these data we calculate the first term of the accounting equation (8): $\alpha_{c} \Delta \ln R_{t}$. While theoretically important these terms are almost identical across states because the rental rate of capital is common nationwide and the shares $\alpha_{c}$ are almost identical across states. Most of the action in identifying different HNTP across states comes from the second term of equation (8), $\left(1-\alpha_{c}\right) \Delta \ln \left(\tilde{w}_{c t}\right)$. We first 
compute the "adjustment factor" $\left(l_{c t}^{\sigma}+\Lambda_{c t} h_{c t}^{\sigma}\right)^{\frac{1}{\sigma}}$, then we divide the average wage by this factor and compute the log change multiplying it by the share of income to labor. As $\sigma$ is very important in calculating the adjustment factor using different estimates of the parameter may have a relevant effect on the estimates of HNTP. Adding the two terms we obtain an accounting measure of $\Delta \ln \left(\Omega_{\mathrm{ct}}\right)$. The average value of this term across states in each decade is reported in Table A1. The average growth rates (1950-90) by state are reported in Table A2 (using $\sigma=0.36$ ) and Table A3 (using $\sigma=0.49$ ). Notice that the behavior of average HNTP is quite different over decades. While in the 50-70 period HNTP is positive or close to 0 (depending on the estimates) in the $70-90$ period it is large and negative. Vis a vis a continued positive SBTP throughout the 1950-90 period, during the early decades HNTP averaged a moderate positive growth but the after 1970 it experienced relatively large negative change. This confirms the previous findings of Caselli and Coleman (2002b) who, by looking at the aggregate U.S. behavior, observed increasing efficiency of both skilled and unskilled labor in the sixties, while since the seventies they measured an increase in skilled labor efficiency together with a decrease in unskilled labor efficiency. Although, in their main specification Caselli and Coleman (2002b) include complementarity between physical capital and skilled workers their "simplified specification" (mentioned at page 150-151) without capital is totally analogous to ours. In such specification what they call unskilled labor efficiency (in logs) would be equal to $\left(1-\alpha_{\mathrm{c}}\right) \ln \left(\Omega_{\mathrm{ct}}\right)$, while what they call skilled labor efficiency (in $\left.\operatorname{logs}\right)$ would be equal to $\left(1-\alpha_{\mathrm{c}}\right) \ln \left(\Omega_{\mathrm{ct}}\right)+\ln \left(\Lambda_{\mathrm{ct}}\right)$. Calculating the growth rates of these terms over decades for the average of the states, we confirm an average growth of unskilled labor efficiency by $0.4 \%$ per year during the period 1950-70 while there was a negative growth of $-2.5 \%$ a year in the 1970-90 period. Skilled labor efficiency, to the contrary, increased during the whole 1950-1990 period at an average of $4.6 \%$ per year in the fifties and sixties and of $5.1 \%$ per year in the seventies and eighties.

\subsection{Technological Progress Frontier}

Interestingly, the negative correlation between SBTP (high in the period 1950-70 and low in the period 1970-90) and HNTP (Lower in 1950-70 than in 1970-90) is not only an aggregate phenomenon concerning the whole U.S. If we consider the SBTP and HNTP in each decade for each state and we plot them, one against the other we see an interesting pattern. Figure 3 shows the plot for the fifties while Figure 4 reproduces the plot for the eighties. Each point is the combination of SBTP and HNTP for one of the 48 continental U.S. states during one decade. The visual impression, confirmed by the OLS coefficients estimated separately for each decade and reported in 
Table 6, suggests that a clear and increasingly steep and tight trade off between SBTP and HNTP across states existed throughout the period and strengthened over time and much in the eighties. While a weaker and less precise relation between these two forms of technological progress is present during the early decade (Figure 3), in the 1980's states willing to give up some Hicks neutral technological progress could benefit from higher skill biased technological progress in a tight almost one to one fashion (Figure 4). All states, over time, moved to a type of progress with lower and even negative Hicks neutral growth in the seventies and eighties and to higher skill biased progress. Moreover, those states that were willing to sacrifice more Hicks neutral growth could achieve higher skill biased growth. Interestingly, the technological opportunity frontier available to US States, became more and more efficient in producing skill-biased progress over the decades since 1950, as the estimates show. Using the estimates of Table $6(\sigma=0.49)$ we can calculate that in the fifties, by giving up one standard deviation of HNTP a state gained $60 \%$ of a standard deviation in SBTP equal to roughly $1.2 \%$ extra growth in skill-biased Technological progress per year. In the eighties a decrease of one standard deviation in HNTP would have granted an extra $90 \%$ of a standard deviation of SBTP, roughly $1.6 \%$ faster growth of this type of progress per year.

\section{Figure 3}

Trade-Off between SBTP and HNTP across US states in the fifties $(\sigma=0.36)$ U.S. States, period 1950-60

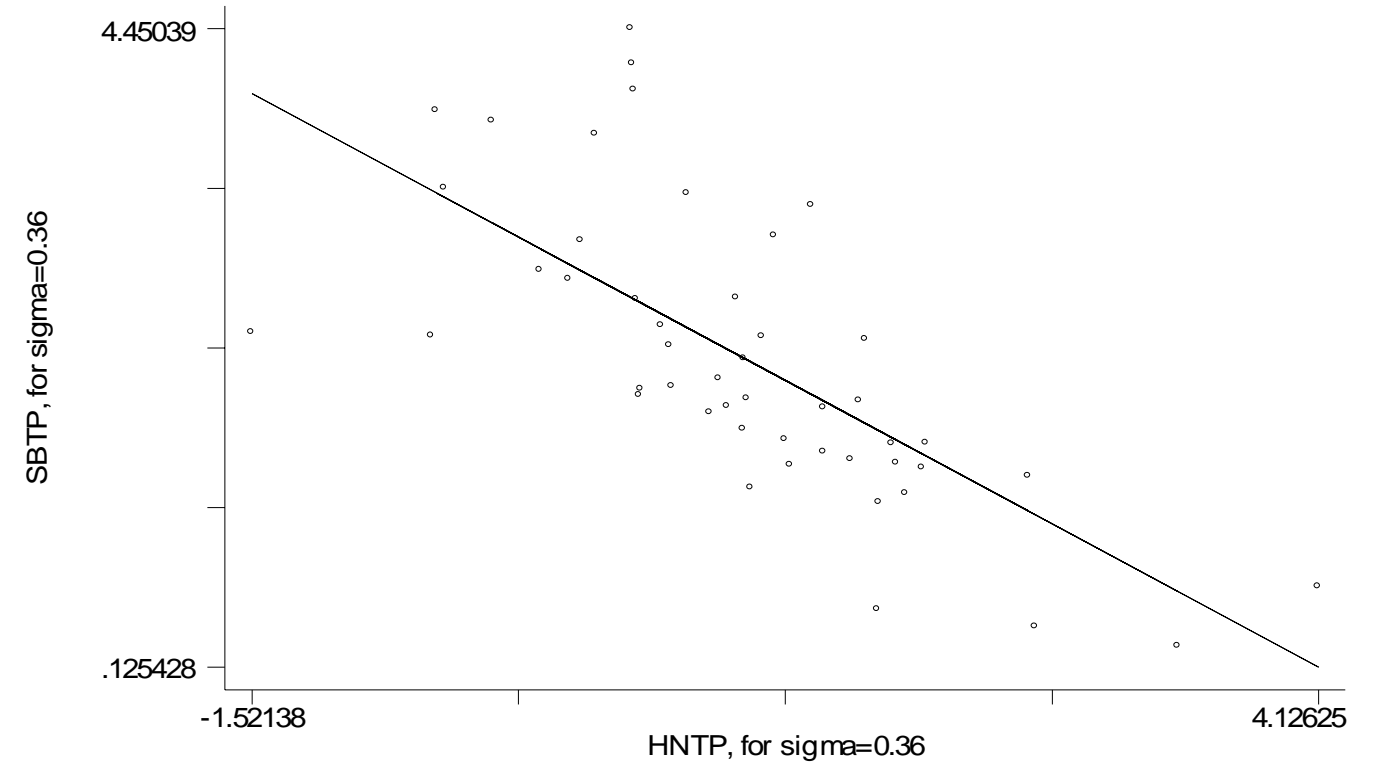




\section{Figure 4}

Trade-Off Between SBTP and HNTP across US states in the eighties $(\sigma=0.36)$

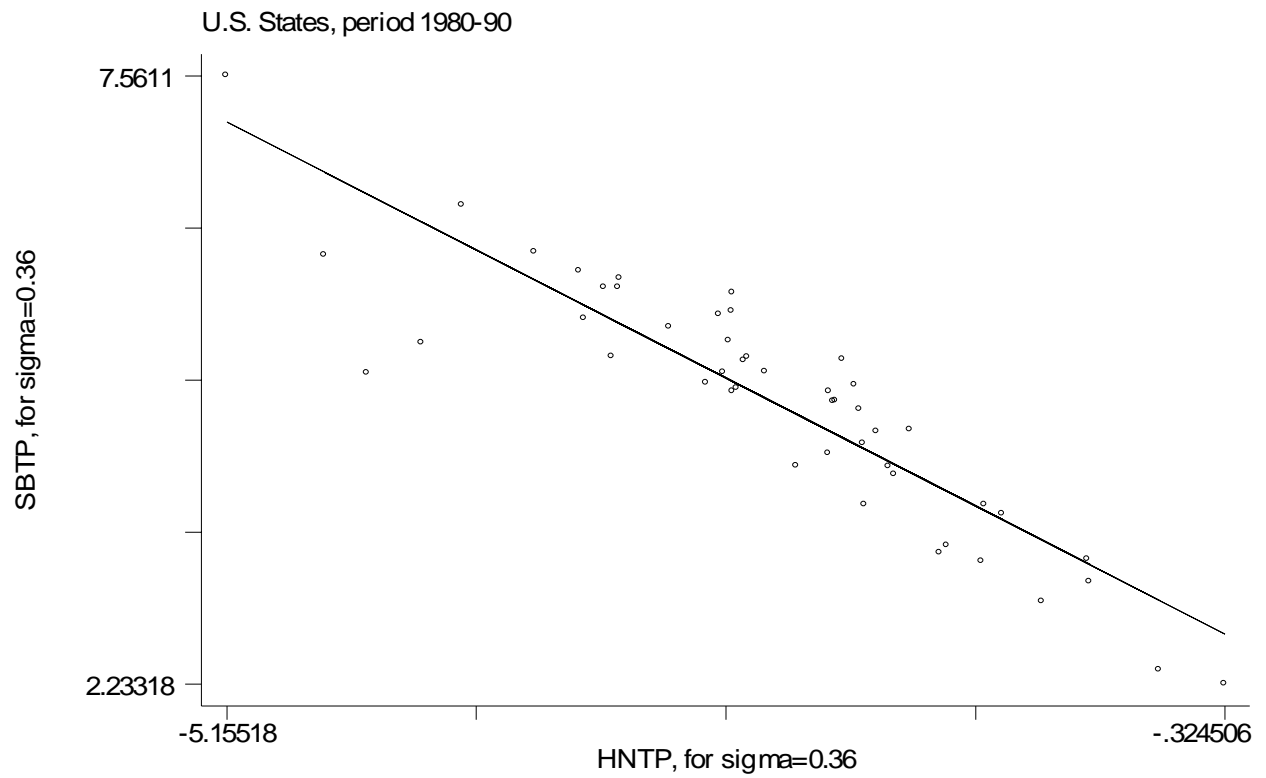

Table 6

Trade-off between SBTP and HNTP across US states in different Decades Dependent variable: $\Delta \ln \left(\Lambda_{\mathrm{ct}}\right)$

\begin{tabular}{|c|c|c|c|c|}
\hline Decade & $\begin{array}{c}\text { Coefficient on } \\
\Delta \ln \left(\Omega_{\mathrm{ct}}\right)\end{array}$ & $\mathbf{R}^{2}$ & $\begin{array}{c}\text { Coefficient on } \\
\Delta \ln \left(\Omega_{\mathrm{ct}}\right)\end{array}$ & $\mathbf{R}^{2}$ \\
\hline Value of $\sigma$ used & \multicolumn{2}{|c|}{$\sigma=0.36$} & \multicolumn{2}{c|}{$\sigma=0.49$} \\
\hline 50 's & $\begin{array}{c}-0.68 * * * \\
(0.13)\end{array}$ & 0.49 & $\begin{array}{c}-0.60^{* * *} \\
(0.13)\end{array}$ & 0.36 \\
& $-0.79 * * *$ & 0.53 & $\begin{array}{c}-0.70^{* * *} \\
(0.11)\end{array}$ & 0.50 \\
\hline 60 's & $(0.11)$ & & $\begin{array}{c}-0.78^{* * *} \\
(0.10)\end{array}$ & 0.70 \\
\hline 70 's & $-0.80^{* * *}$ & 0.59 & $-0.87 * * *$ & 0.85 \\
& $(0.10)$ & & $0.06)$ & \\
\hline 80 's & $-0.92^{* * *}$ & 0.80 & & \\
& $(0.09)$ & & & \\
\hline
\end{tabular}

The dependent and independent variables have been standardized by their std. deviation so coefficients are comparable across regressions $* * *=$ significant at $1 \%$ level

Number of Observation in each regression: 48. 


\section{Discussion and Conclusions}

Our findings suggest that the technologies introduced during the considered period, and particularly those introduced during the eighties presented U.S. states with a menu of options. The representative firm in a state could adopt a technological path with a faster skill-biased technological change relative to another state. However, such choice implied a "cost" in terms of Hicks neutral technological change to be traded off against the gain of skill-biased progress. We may think of the technological menu as a more or less intense undertaking of a new technology. For the eighties, in which this phenomenon is most prominent, we can actually think of a new general purpose technology (GPT) being introduced that corresponds to what is generally defined as information and communication technology (ICT). This technology generated productivity gains concentrated among the skilled workers but required relevant restructuring of the productive tasks that probably disrupted the productivity of less skilled workers. Previous technologies (since the fifties) seem to have worked in a similar way but ICT made the trade off more drastic. Several studies have stressed that the adoption of new technology may generate a period of decrease in productivity, when the technology is new as the restructuring decreases efficiency. Helpman and Trajtenberg (1998) characterize the initial phase of a new technology as "a time to sow" while only when the supply of factors complementary to the new technology has increased there are benefit in productivity to "be reaped". Atkeson and Kehoe (2001) emphasize how it takes some time before a new vintage of technologies is incorporated into the production process and this causes a delay between technology diffusion and the effects on productivity. Our findings, however, emphasize how the gains of the adoption of the new technology are not uniformly distributed across skills. The adoption of more intensely skill-biased technology caused U.S. states to give up Hicks neutral progress often to the extent that the net effect was negative growth of efficiency of the unskilled.

This paper is able to measure these important characteristics of technological progress in the United States by looking at differences across states during the period 1950-1990. As the U.S. states are at the frontier of technology, measuring and characterizing their technological progress provide important insights into the process of generating and adopting new technologies. This is made possible as we produce a methodologically sound and precise estimate of the elasticity of substitution between skilled and unskilled. We do this by using comparable and precise Census data across U.S. states, a long time period and instruments that are more exogenous than those typically used in cross country studies. As a result we obtain a set of elasticity estimates most of them in the range between 1.55 and 1.96 . 
The interesting fact emerging from our analysis of SBTP and HNTP is that across U.S. States the actual choice of technological path was quite different. In particular we are the first to document the existence of a technological trade-off for U.S. States between options that are more or less intensive in skill-biased technological progress. Different states were on different paths which corresponded to different combinations of Hicks-neutral and skill-biased technological progress. Our main results confirm and strengthen the finding of Caselli and Colemann (2002a, b), who first identified such trade-off. 


\section{References}

Acemoglu D. (1998) "Why do New Technology complement Skills? Directed Technological Change and Wage Inequality" Quarterly Journal of Economics, 113, pp. 1055-1098.

Acemoglu D. and F.Zilibotti (2001) "Productivity Differences” Quarterly Journal of Economics" , 116 (2) 563-606

Acemoglu D. and J. Angrist (2000) "How Large are Human Capital Externalities? Evidence from Compulsory Schooling Laws” NBER Macroeconomics Annual, MIT Press, Boston MA.

Atkeson A. and P. Kehoe (2001) "The Transition to a New Economy After the Second Industrial Revolution” Federal reserve Bank of Minneapolis Staff Report June 2001.

Atkison A. and J. Stiglitz (1969) "A new view of Technological Change", Economic Journal: 573578.

Autor D. and L. Katz (1999) "Changes in the Wage Structure and Earnings Inequality", in Handbook of Labor Economics Volume 3a, eds. Orley Ashenfelter and David Card, 14631555, Amsterdam: Elsevier.

Basu S. and D.Weil (1998) “Appropriate Technology and Growth" The Quarterly Journal of Economics 113(4): 1025-54.

Berman E. J. Bond and Z. Griliches (1994) "Changes for the Demand for Skilled Labor Within U.S. Manufacturing Industries" Quarterly Journal of Economics, 109, 367-98

Bowles S. (1970) "Aggregation of Labor Inputs in the Economics of Growth and Planning: Experiments with a Two-Level CES Function” Journal of Political Economy, 78 (1), pp.7881.

Bils M. and Klenow (1998) "Does Schooling Cause Growth? American Economic Review, Dec. 2000, 90, 1160-1193.

Bound J. and G.E. Johnson "Changes in the Structure of Wages in 1980s : An Evaluation of Alternative Explanations", American Economic Review, 82, 371-92

Bureau of Economic Analysis (2003): Data on Personal Income per Capita at the source:http://www.bea.gov/bea/regional/spi

Card D. and J. DiNardo (2002) "Skill-Biased Technological Change and Wage Inequality: Some Problems and Puzzles" Journal of Labor Economics, 20 (4) 733-783.

Caselli F. and Coleman (2002a) “The World Technology Frontier” NBER Working Paper 7904, Boston, Ma.

Caselli F. and Coleman (2002b) "The U.S. Technology Frontier” American Economic Association Papers and Proceedings, 92 (3), 148-152. 
Chao J. and N. Swanson (2002) "Consistent Estimation with a Large Number of Weak Instruments" mimeo, University of Maryland, Sep. 2002.

Ciccone A. and G. Peri (2002) "Identifying Human Capital Externalities: Theory with an Application to US Cities” IZA working Paper \# 488

Doepke M. and F. Zilibotti (2003) "Voting with Your Children: a Positive Analysis of Child Labor Laws" mimeo University of California, Los Angeles, Feb. 2003.

Dougherty C.R.S. (1972) "Estimation of Labor Aggregation Functions" Journal of Political Economy, 80 (6) pp. 1101-1119.

Fuller W. (1977) "Some Properties of a Modification of the Limited Information Estimator" Econometrica 45 (4) 939-954.

Gollin D. (2002) “Getting Income Shares Right” Journal of Political Economy, 100 (2), 458-474.

Gordon R. (2000) "Does the New Economy measure up to the Great Inventions of the past?" Journal of Economic Perspectives

Hahn J. and J. Hausman (2002) "Weak Instruments: Diagnosis and Cures in Empirical Econometrics" mimeo MIT, 2002.

Helpman E. and M. Trajtenberg (1998) "Diffusion of General Purpose Technology" in "General Purpose Technology and Economic Growth", Elhanan Helpman Editor, MIT Press, Cambridge, Ma.

Hendricks L. (2002) "How Important is Human Capital for Development? Evidence from Immigrant Earnings" American Economics Review, 92 (1), 198-219.

Hsieh C.T. (2002) "What Explain the Industrial Revolution in East Asia? Evidence from the Factor Markets”, American Economic Review, 92(3) 502-26.

Johnson G.E. (1997) "Change in Earning Inequality: the Role of Demand Shifts" Journal of Economic Perspectives, 11 (2) p. 41-54

Jones C. (2002) "Sources of U.S. Economic Growth in a world of Ideas" American Economic Review

Jorgenson D.W. and K.J. Stiroh (2000) "Raising the Speed Limit: U.S. Economic Growth in the information age" Brookings Paper on Economic Activity, 125-235.

Katz L. and K. Murphy (1992) "Change in Relative Wages 1963-1987: Supply and Demand Factors" Quarterly Journal of Economics, 107 (1), 35-78.

Klenow P. and A. Rodriguez-Clare (1997) "The Neoclassical Revival in Growth Economics: Has it Gone Too Far?" in Ben S.Bernanke and Julio J.Rotemberg eds. NBER Macroeconomic Annual 1997, Cambridge Ma. MIT Press. 
Krusell P. Ohanian, V. Rios-Rull and G. Violante (2000) "Capital-Skill Complementarity and inequality: A Macroeconomic Analysis" Econometrica 68 (5): 1029-53.

Murphy K., C. Riddle and P. Romer (1998) "Wages, Skills and Technology in the United States and Canada" in "General Purpose Technology and Economic Growth", Elhanan Elpman Editor, MIT Press, Cambridge, Ma.

Oliner S. and D. Sichel (2000) “The resurgence of Growth in the late 1990's: is information technology the story? Journal of Economic Perspectives.

Solow R. (1956) "A Contribution to the Theory of Economic Growth" Quarterly Journal of Economics, 70, pp. 65-94.

Solow R. (1957) "Technical Change and the Aggregate Production Function", Review of Economics and Statistics 39, pp.312-320.

Stock J., J. Wright and M. Yogo (2002) “A Survey of Weak Instruments and Weak Identification in Generalized Method of Moments” Journal of Business and Economic Statistics, 20 (4) 51829.

Woolridge J. L. (2001) "Econometric Analysis of Cross Section and Panel Data" MIT Press, Boston Ma. 


\section{A. Data Appendix}

The paper uses data from the 1950, 60, 70, 80 and 90 IPUMS files in order to calculate the relative supply of skills and relative wages. The extract is exactly the same used in the work by Acemoglu and Angrist (2000) and kindly provided to us by the authors. The extract includes USborn individuals white men aged 21-59. We exclude the non-continental states (Alaska and Hawaii) and D.C. The observations are weighted by the IPUMS weighting variable (SLWT). The schooling of individuals was divided into the four base-groups (HS dropouts, HS, College Dropouts and College Graduates) using the variable HIGRADED for the 1950-80 data and the variable YEARSCH for the 1990 census. The variable used to calculate wages is weekly wage obtained by dividing yearly wage (wage and salary income) by the number of weeks worked. Wages are topcoded uniformly across census years. The censoring is at the $98^{\text {th }}$ percentile using the $98^{\text {th }}$ percentile times 1.5.

The data on child labor laws and compulsory attendance laws are described in the Appendix of Acemoglu and Angrist 2000. Data on income are from the Bureau of Economic Analysis. The data on real wages are calculated using nominal weekly wages from the IPUMS data and deflating them by using the GDP deflator from the BEA. These data are more precise than estimates obtained from aggregate wage data as, previous to 1969 , the data on employed are rather imprecise.

Table A1 and A2 report the estimates of $\ln \left(\Lambda_{\mathrm{ct}}\right)$, the skill-biased technological level and its average yearly growth rate for the following decade. Table 1 reports the values averaging across different states for each decade, Table A2 reports the values of averaging across decades for each state. Table A3 and A4 report the estimates of $\ln \left(\Omega_{\mathrm{ct}}\right)$, the Hicks-Neutral technological level and its average yearly growth rate for the following decade 
Table A1

Average SBTP and HNTP for US states in each decade.

\begin{tabular}{|l|l|l|l|l|}
\hline Decade & $\begin{array}{l}\text { Average } \\
\text { yearly } \\
\text { HNTP }\end{array}$ & $\begin{array}{l}\text { Average } \\
\text { Yearly } \\
\text { SBTP }\end{array}$ & $\begin{array}{l}\text { Average } \\
\text { yearly } \\
\text { HNTP }\end{array}$ & $\begin{array}{l}\text { Average } \\
\text { Yearly } \\
\text { SBTP }\end{array}$ \\
\hline Value of $\sigma$ used & \multicolumn{3}{|c|}{$\sigma=0.36$} & \multicolumn{2}{c|}{$\sigma=0.49$} \\
\hline 1950 's & $+0.8 \%$ & $+4.8 \%$ & +1.3 & $+4.3 \%$ \\
\hline 1960 's & $-1.0 \%$ & $+5.8 \%$ & $-0.1 \%$ & $+4.9 \%$ \\
\hline 1970 's & $-4.8 \%$ & $+5.1 \%$ & $-3.4 \%$ & +4.1 \\
\hline 1980 's & $-3.5 \%$ & $+7.0 \%$ & $-1.5 \%$ & +6.1 \\
\hline
\end{tabular}

Table A2

Average (yearly) HNTP and SBTP by state over the period 1950-1990 $(\sigma=0.36)$

\begin{tabular}{|l|r|r|l|r|r|}
\hline State & \multicolumn{1}{|l}{ HNTP } & \multicolumn{1}{l|}{ SBTP } & State & HNTP & \multicolumn{1}{l|}{ SBTP } \\
\hline Arizona & -0.036 & 0.082 & Kentucky & -0.013 & 0.057 \\
\hline New Mexico & -0.037 & 0.069 & Michigan & -0.018 & 0.057 \\
\hline Maine & -0.022 & 0.067 & Tennessee & -0.017 & 0.057 \\
\hline Arkansas & -0.020 & 0.066 & Texas & -0.027 & 0.057 \\
\hline Colorado & -0.025 & 0.066 & Massachusetts & -0.023 & 0.056 \\
\hline New Hampshire & -0.021 & 0.064 & Nebraska & -0.025 & 0.056 \\
\hline Montana & -0.028 & 0.063 & Alabama & -0.020 & 0.056 \\
\hline North Carolina & -0.021 & 0.063 & Virginia & -0.021 & 0.055 \\
\hline Pennsylvania & -0.025 & 0.063 & Georgia & -0.020 & 0.054 \\
\hline California & -0.029 & 0.063 & Ohio & -0.019 & 0.053 \\
\hline New Jersey & -0.027 & 0.063 & Missouri & -0.019 & 0.053 \\
\hline Florida & -0.027 & 0.063 & Wisconsin & -0.021 & 0.053 \\
\hline Wyoming & -0.033 & 0.062 & Iowa & -0.024 & 0.052 \\
\hline Connecticut & -0.029 & 0.062 & Vermont & -0.016 & 0.051 \\
\hline Idaho & -0.026 & 0.062 & Louisiana & -0.027 & 0.050 \\
\hline Utah & -0.027 & 0.061 & Delaware & -0.029 & 0.049 \\
\hline West Virginia & -0.015 & 0.061 & Kansas & -0.023 & 0.049 \\
\hline New York & -0.030 & 0.060 & Mississippi & -0.017 & 0.048 \\
\hline Minnesota & -0.023 & 0.060 & Nevada & -0.020 & 0.047 \\
\hline Illinois & -0.026 & 0.059 & Indiana & -0.015 & 0.046 \\
\hline Oregon & -0.025 & 0.059 & Oklahoma & -0.018 & 0.046 \\
\hline Maryland & -0.022 & 0.059 & Rhode Island & -0.016 & 0.044 \\
\hline South Carolina & -0.018 & 0.058 & North Dakota & -0.013 & 0.043 \\
\hline Washington & -0.026 & 0.058 & South Dakota & -0.017 & 0.037 \\
\hline
\end{tabular}


Table A3

Average (yearly) HNTP and SBTP by state over the period 1950-1990 $(\sigma=0.49)$

\begin{tabular}{|l|r|r|l|r|r|}
\hline name & HNTP & SBTP & name & HNTP & SBTP \\
\hline Arizona & -0.020 & 0.074 & Kentucky & -0.005 & 0.049 \\
\hline New Mexico & -0.020 & 0.061 & Washington & -0.013 & 0.049 \\
\hline Maine & -0.011 & 0.059 & Michigan & -0.008 & 0.049 \\
\hline Arkansas & -0.009 & 0.058 & Texas & -0.013 & 0.049 \\
\hline Colorado & -0.013 & 0.057 & Massachusetts & -0.011 & 0.048 \\
\hline New Hampshire & -0.009 & 0.055 & Alabama & -0.009 & 0.048 \\
\hline Florida & -0.014 & 0.055 & Virginia & -0.010 & 0.047 \\
\hline Montana & -0.015 & 0.055 & Nebraska & -0.011 & 0.046 \\
\hline Pennsylvania & -0.013 & 0.055 & Ohio & -0.009 & 0.045 \\
\hline California & -0.015 & 0.055 & Georgia & -0.009 & 0.045 \\
\hline North Carolina & -0.009 & 0.054 & Missouri & -0.009 & 0.044 \\
\hline Wyoming & -0.015 & 0.054 & Iowa & -0.011 & 0.043 \\
\hline West Virginia & -0.007 & 0.054 & Wisconsin & -0.010 & 0.043 \\
\hline Idaho & -0.014 & 0.054 & Vermont & -0.007 & 0.043 \\
\hline Utah & -0.014 & 0.054 & Louisiana & -0.012 & 0.042 \\
\hline New Jersey & -0.013 & 0.053 & Delaware & -0.015 & 0.041 \\
\hline Connecticut & -0.015 & 0.053 & Kansas & -0.011 & 0.040 \\
\hline New York & -0.015 & 0.051 & Mississippi & -0.006 & 0.040 \\
\hline Illinois & -0.013 & 0.051 & Nevada & -0.009 & 0.040 \\
\hline Oregon & -0.013 & 0.050 & Indiana & -0.006 & 0.039 \\
\hline Maryland & -0.010 & 0.050 & Oklahoma & -0.008 & 0.038 \\
\hline South Carolina & -0.008 & 0.050 & Rhode Island & -0.006 & 0.036 \\
\hline Tennessee & -0.007 & 0.050 & North Dakota & -0.002 & 0.033 \\
\hline Minnesota & -0.010 & 0.049 & South Dakota & -0.005 & 0.028 \\
\hline
\end{tabular}




\section{CESifo Working Paper Series}

(for full list see www.cesifo.de)

960 Aaron Tornell and Frank Westermann, Credit Market Imperfections in Middle Income Countries, June 2003

961 Hans-Werner Sinn and Wolfgang Ochel, Social Union, Convergence and Migration, June 2003

962 Michael P. Devereux, Measuring Taxes on Income from Capital, June 2003

963 Jakob de Haan, Jan-Egbert Sturm and Bjørn Volkerink, How to Measure the Tax Burden on Labour at the Macro-Level?, June 2003

964 Harry Grubert, The Tax Burden on Cross-Border Investment: Company Strategies and Country Responses, June 2003

965 Kirk A. Collins and James B. Davies, Measuring Effective Tax Rates on Human Capital: Methodology and an Application to Canada, June 2003

966 W. Steven Clark, Using Micro-Data to Assess Average Tax Rates, June 2003

967 Christopher Heady, The 'Taxing Wages' Approach to Measuring the Tax Burden on Labour, June 2003

968 Michael P. Devereux and Alexander Klemm, Measuring Taxes on Income from Capital: Evidence from the UK, June 2003

969 Bernhard Eckwert and Itzhak Zilcha, The Effect of Better Information on Income Inequality, June 2003

970 Hartmut Egger and Josef Falkinger, The Role of Public Infrastructure for Firm Location and International Outsourcing, June 2003

971 Dag Morten Dalen and Trond E. Olsen, Regulatory Competition and Multi-national Banking, June 2003

972 Matthias Wrede, Tax Deductibility of Commuting Expenses and Residential Land Use with more than one Center, June 2003

973 Alessandro Cigno and Annalisa Luporini, Scholarships or Student Loans? Subsidizing Higher Education in the Presence of Moral Hazard, June 2003

974 Chang Woon Nam, Andrea Gebauer and Rüdiger Parsche, Is the Completion of EU Single Market Hindered by VAT Evasion?, June 2003 
975 Michael Braulke and Giacomo Corneo, Capital Taxation May Survive in Open Economies, July 2003

976 Assar Lindbeck, An Essay on Welfare State Dynamics, July 2003

977 Henrik Jordahl and Luca Micheletto, Optimal Utilitarian Taxation and Horizontal Equity, July 2003

978 Martin D. D. Evans and Richard K. Lyons, Are Different-Currency Assets Imperfect Substitutes?, July 2003

979 Thorsten Bayindir-Upmann and Frank Stähler, Market Entry Regulation and International Competition, July 2003

980 Vivek Ghosal, Firm and Establishment Volatility: The Role of Sunk Costs, Profit Uncertainty and Technological Change, July 2003

981 Christopher A. Pissarides, Unemployment in Britain: A European Success Story, July 2003

982 Wolfgang Buchholz, Richard Cornes, and Wolfgang Peters, On the Frequency of Interior Cournot-Nash Equilibria in a Public Good Economy, July 2003

983 Syed M. Ahsan and Panagiotis Tsigaris, Choice of Tax Base Revisited: Cash Flow vs. Prepayment Approaches to Consumption Taxation, July 2003

984 Campbell Leith and Jim Malley, A Sectoral Analysis of Price-Setting Behavior in US Manufacturing Industries, July 2003

985 Hyun Park and Apostolis Philippopoulos, Choosing Club Membership under Tax Competition and Free Riding, July 2003

986 Federico Etro, Globalization and Political Geography, July 2003

987 Dan Ariely, Axel Ockenfels and Alvin E. Roth, An Experimental Analysis of Ending Rules in Internet Auctions, July 2003

988 Paola Conconi and Carlo Perroni, Self-Enforcing International Agreements and Domestic Policy Credibility, July 2003

989 Charles B. Blankart and Christian Kirchner, The Deadlock of the EU Budget: An Economic Analysis of Ways In and Ways Out, July 2003

990 M. Hasham Pesaran and Allan Timmermann, Small Sample Properties of Forecasts from Autoregressive Models under Structural Breaks, July 2003

991 Hyun Park, Apostolis Philippopoulos and Vangelis Vassilatos, On the Optimal Size of Public Sector under Rent-Seeking competition from State Coffers, July 2003 
992 Axel Ockenfels and Alvin E. Roth, Late and Multiple Bidding in Second Price Internet Auctions: Theory and Evidence Concerning Different Rules for Ending an Auction, July 2003

993 Pierre Salmon, The Assignment of Powers in an Open-ended European Union, July 2003

994 Louis N. Christofides and Chen Peng, Contract Duration and Indexation in a Period of Real and Nominal Uncertainty, July 2003

995 M. Hashem Pesaran, Til Schuermann, Björn-Jakob Treutler, and Scott M. Weiner, Macroeconomic Dynamics and Credit Risk: A Global Perspective, July 2003

996 Massimo Bordignon and Sandro Brusco, On Enhanced Cooperation, July 2003

997 David F. Bradford, Addressing the Transfer-Pricing Problem in an Origin-Basis X Tax, July 2003

998 Daniel Gros, Who Needs Foreign Banks?, July 2003

999 Wolfram Merzyn and Heinrich W. Ursprung, Voter Support for Privatizing Education: Evidence on Self-Interest and Ideology, July 2003

1000 Jo Thori Lind, Fractionalization and the Size of Government, July 2003

1001 Daniel Friedman and Donald Wittman, Litigation with Symmetric Bargaining and TwoSided Incomplete Information, July 2003

1002 Matthew Clarke and Sardar M. N. Islam, Health Adjusted GDP (HAGDP) Measures of the Relationship Between Economic Growth, Health Outcomes and Social Welfare, July 2003

1003 Volker Grossmann, Contest for Attention in a Quality-Ladder Model of Endogenous Growth, August 2003

1004 Marcel Gérard and Joan Martens Weiner, Cross-Border Loss Offset and Formulary Apportionment: How do they affect multijurisdictional firm investment spending and interjurisdictional tax competition?, August 2003

1005 Burkhard Heer, Nonsuperneutrality of Money in the Sidrauski Model with Heterogeous Agents, August 2003

1006 V. Anton Muscatelli, Piergiovanna Natale, and Patrizio Tirelli, A Simple and Flexible Alternative to the Stability and Growth Pact Deficit Ceilings. Is it at hand?, August 2003

1007 Reto Foellmi and Josef Zweimüller, Inequality and Economic Growth: European Versus U.S. Experiences, August 2003

1008 James S. Costain and Michael Reiter, Business Cycles, Unemployment Insurance, and the Calibration of Matching Models, August 2003 
1009 Marco Runkel, Optimal Contest Design when the Designer's Payoff Depends on Competitive Balance, August 2003

1010 Donald O. Parsons, Torben Tranaes and Helene Bie Lilleør, Voluntary Public Unemployment Insurance, August 2003

1011 Rüdiger Pethig and Andreas Wagener, Profit Tax Competition and Formula Apportionment, August 2003

1012 Johan Willner, Privatisation and Public Ownership in Finland, August 2003

1013 Seppo Kari and Jouko Ylä-Liedenpohja, Taxation and Valuation of International Real Investments, August 2003

1014 James Heckman, Rosa Matzkin and Lars Nesheim, Simulation and Estimation of Hedonic Models, August 2003

1015 Biswa N. Bhattacharyay, Towards a Macro-Prudential Leading Indicators Framework for Monitoring Financial Vulnerability, August 2003

1016 J. Stephen Ferris and Stanley L. Winer, Searching for Keynes: With Application to Canada, 1870-2000, August 2003

1017 Massimo Bordignon, Luca Colombo and Umberto Galmarini, Fiscal Federalism and Endogenous Lobbies' Formation, August 2003

1018 Annette Alstadsæter, The Dual Income Tax and Firms'Income Shifting through the Choice of Organizational Form and Real Capital Investments, August 2003

1019 Peter Fredriksson and Bertil Holmlund, Optimal Unemployment Insurance Design: Time Limits, Monitoring, or Workfare?, August 2003

1020 Kashif S. Mansori, Following in their Footsteps: Comparing Interest Parity Conditions in Central European Economies to the Euro Countries, August 2003

1021 Christoph Borgmann and Matthias Heidler, Demographics and Volatile Social Security Wealth: Political Risks of Benefit Rule Changes in Germany, August 2003

1022 Kjell Erik Lommerud, Bjørn Sandvik and Odd Rune Staume, Good Jobs, Bad Jobs and Redistribution, August 2003

1023 Patrick Karl O'Brien, The Governance of Globalization: The Political Economy of Anglo-American Hegemony, 1793-2003, September 2003

1024 Antonio Ciccone and Giovanni Peri, Skills' Substitutability and Technological Progress: U.S. States 1950-1990, September 2003 